\title{
Interrogating COVID-19 vaccine intent in the Philippines with a nationwide open-access online survey
}

Alexandria Caple ${ }^{1}$, Arnie Dimaano ${ }^{2}$, Marc Martin Sagolili ${ }^{2}$, April Anne Uy ${ }^{2}$, Panjee Mariel Aguirre ${ }^{3}$, Dean Lotus Alano $^{2}$, Giselle Sophia Camaya ${ }^{2}$, Brent John Ciriaco ${ }^{3}$, Princess Jerah Mae Clavo ${ }^{2}$, Dominic Cuyugan ${ }^{2}$, Cleinne Florence Geeseler Fermo ${ }^{2}$, Paul Jeremy Lanete ${ }^{2}$, Ardwayne Jurel La Torre ${ }^{3}$, Thomas Loteyro $^{3}$, Raisa Mikaela Lua ${ }^{2}$ , Nicole Gayle Manansala ${ }^{2}$, Raphael Willard Mosquito ${ }^{2}$, Alexa Octaviano ${ }^{2}$, Alexandra Erika Orfanel ${ }^{2}$, Gheyanna Merly Pascual $^{2}$, Aubrey Joy Sale ${ }^{2}$, Sophia Lorraine Tendenilla ${ }^{2}$, Maria Sofia Lauren Trinidad ${ }^{2}$, Nicole Jan Trinidad ${ }^{2}$, Daphne Louise Verano ${ }^{2}$, Nicanor Austriaco ${ }^{\text {Corresp. } 2,4}$

1 Psychology, Providence College, Providence, RI, United States

2 Biological Sciences, University of Santo Tomas, Manila, Philippines

3 Advertising Arts, University of Santo Tomas, Manila, Philippines

4 Biology, Providence College, Providence, RI, United States

Corresponding Author: Nicanor Austriaco

Email address: naustria@providence.edu

To mitigate the unprecedented health, social, and economic damage of COVID-19, the Philippines is undertaking a nationwide vaccination program to mitigate the effects of the global pandemic. In this study, we interrogated COVID-19 vaccine intent in the country by deploying a nationwide open-access online survey, two months before the rollout of the national vaccination program. The Health Belief Model (HBM) posits that people are likely to adopt disease prevention behaviors and to accept medical interventions like vaccines if there is sufficient motivation and cues to action. A majority of our 7,193 respondents $(62.5 \%)$ indicated that they were willing to be vaccinated against COVID-19. Moreover, multivariable analysis revealed that HBM constructs were associated with vaccination intention in the Philippines. Perceptions of high susceptibility, high severity, and significant benefits were all good predictors for vaccination intent. We also found that external cues to action were important. Large majorities of our respondents would only receive the COVID-19 vaccines after many others had received it (72.8\%) or after politicians had received it (68.2\%). Finally, our study revealed that most (21\%) were willing to pay an amount of PHP1,000 [USD20] for the COVID-19 vaccines with an average willing-to-pay amount of PHP1,892 [USD38]. 
1

2

3

4

5

6

7

8

9

10

11

12

13

14

15

16

17

18

19

20

21

22

23

24

25

26

27

28

29

30

\section{Interrogating COVID-19 Vaccine Intent in the Philippines with a Nationwide Open-Access Online Survey}

Alexandria Caple ${ }^{1}$, Arnie O. Dimaano ${ }^{2+}$, Marc Martin C. Sagolili2+, April Anne M. $\mathrm{Uy}^{2+}$, Panjee Mariel G. Aguirre ${ }^{3}$, Dean Lotus C. Alano ${ }^{2}$, Giselle Sophia M. Camaya $^{2}$, Brent John A. Ciriaco ${ }^{3}$, Princess Jerah S. Clavo ${ }^{2}$, Dominic G. Cuyugan ${ }^{2}$, Cleinne Florence Geeseler V. Fermo ${ }^{2}$, Paul Jeremy C. Lanete ${ }^{2}$, Ardwayne Jurel D. La Torre ${ }^{3}$, Thomas Albert T. Loteyro ${ }^{3}$, Raisa Mikaela Lua ${ }^{2}$, Nicole Gayle R. Manansala $^{2}$, Raphael Willard M. Mosquito ${ }^{2}$, Alexa Marie C. Octaviano², Alexandra Erika T. Orfanel ${ }^{2}$, Gheyanna Merly U. Pascual ${ }^{2}$, Aubrey Joy S. Sale ${ }^{2}$, Sophia Lorraine S. Tendenilla ${ }^{2}$, Maria Sofia Lauren R. Trinidad ${ }^{2}$, Nicole Jan S. Trinidad $^{2}$, Daphne Louise V. Verano ${ }^{2}$, and Nicanor Austriaco ${ }^{2,4, *}$

\author{
${ }^{1}$ Department of Psychology, Providence College, \\ 1 Cunningham Square, Providence, Rhode Island 02918, U.S.A., \\ ${ }^{2}$ Department of Biological Sciences, University of Santo Tomas, \\ España Blvd., Manila 1015, Philippines, \\ ${ }^{3}$ Department of Advertising Arts, University of Santo Tomas, \\ España Blvd., Manila 1015, Philippines, \\ ${ }^{4}$ Department of Biology, Providence College, \\ 1 Cunningham Square, Providence, Rhode Island 02918, U.S.A.
}

${ }^{+}$These authors contributed equally to the work.

*Corresponding author: Rev. Fr. Nicanor Austriaco, O.P. (naustriaco@ust.edu.ph) 
31

32

33

34

35

36

37

\section{7}

\section{ABSTRACT}

To mitigate the unprecedented health, social, and economic damage of COVID-19, the Philippines is undertaking a nationwide vaccination program to mitigate the effects of the global pandemic. In this study, we interrogated COVID-19 vaccine intent in the country by deploying a nationwide open-access online survey, two months before the rollout of the national vaccination program. The Health Belief Model (HBM) posits that people are likely to adopt disease prevention behaviors and to accept medical interventions like vaccines if there is sufficient motivation and cues to action. A majority of our 7,193 respondents (62.5\%) indicated that they were willing to be vaccinated against COVID-19. Moreover, multivariable analysis revealed that HBM constructs were associated with vaccination intention in the Philippines. Perceptions of high susceptibility, high severity, and significant benefits were all good predictors for vaccination intent. We also found that external cues to action were important. Large majorities of our respondents would only receive the COVID-19 vaccines after many others had received it $(72.8 \%)$ or after politicians had received it (68.2\%). Finally, our study revealed that most (21\%) were willing to pay an amount of PHP1,000 [USD20] for the COVID-19 vaccines with an average willing-to-pay amount of PHP1,892 [USD38]. case of COVID-19, a novel respiratory disease first identified in Wuhan, China, that is caused by the coronavirus, SARS-CoV-2 (Xie et al., 2020; Zhu et al., 2020; Guan et al., 2020). With widespread human-to-human transmission, the virus is highly contagious, and the COVID-19 
55 pandemic is now of global concern (Burki, 2020; Paules, Marston \& Fauci, 2020; Case et al., 2021;

56 Novelli et al., 2021). As of August 25, 2021, there have been 1,883,088 confirmed cases and

57 32,492 deaths from COVID-19 reported by the DOH throughout the archipelago 58 (ncovtracker.doh.gov.ph).

Vaccination has long been regarded as the most effective means for combating infectious

60 disease (Rappuoli et al., 2014; Sathyanarayana et al., 2020). The Philippines began its national

61 vaccine drive against COVID-19 on March 1, 2021, with the goal of vaccinating seventy million

62 of its citizens by the end of the calendar year (Inter-Agency Task Force for the Management of

63 Emerging Infectious Disease, 2021). One of the ongoing challenges for this campaign is the

64 vaccine hesitancy among the Filipino people (Alfonso et al., 2021). Though immunization rates

65 had been relatively high in the Philippines for many decades, the controversial 2016 rollout of the

66 dengue vaccine, Dengvaxia, triggered significant drops in the rates of immunization as Filipino

67 parents refused to have their children routinely vaccinated against polio, chicken pox, and tetanus

68 (Fatima and Syed 2018; Smith 2018).

The Health Belief Model (HBM) posits that people are likely to adopt disease prevention

70 behaviors and to accept medical interventions like vaccines if there is sufficient motivation and

71 cues to action (Rosenstock, Strecher \& Becker, 1988). Motivational factors include perceived

72 susceptibility to and severity of the disease and perceived benefits of the vaccine. Cues to action

73 include information, people, and events that nudge the individual towards vaccination. The HBM

74 has been adopted as a conceptual framework that has been used to evaluate the beliefs and attitudes

75 toward a diversity of vaccines including the influenza, human papillomavirus, and hepatitis B

76 vaccines (Teitler-Regev, Shahrabani \& Benzion, 2011; Donadiki et al., 2014; Hu et al., 2017; Chen

77 et al., 2019). Moreover, several studies have shown that the HBM constructs can serve as an 
78 important predictor of influenza vaccination uptake (Brewer et al., 2007; Shahrabani, Benzion \&

79 Yom Din, 2009; Shahrabani \& Benzion, 2010; Tsutsui, Benzion \& Shahrabani, 2012). During the

80 COVID-19 pandemic, the HBM was used to assess the root causes of COVID-19 vaccine hesitancy

81 in the Asia-Pacific region and beyond (Wong et al., 2020, 2021; Lin et al., 2020; Yu et al., 2021;

82 Kabir et al., 2021; Shmueli, 2021; Huynh et al., 2021; Tao, Wang \& Liu, 2021; Mahmud et al., 83 2021; Banik et al., 2021).

84 In this study, we interrogated COVID-19 vaccine intent in the Philippines by deploying a

85 nationwide open-access online survey, two months before the rollout of the national vaccination

86 program. Based on the HBM framework, we hypothesized that acceptance of a COVID-19 vaccine

87 depends upon beliefs about susceptibility to and severity of COVID-19, and beliefs about the

88 perceived benefits of the vaccine. We also wanted to assess possible cues to vaccination for our 89 Filipino respondents.

90 A majority of our 7,193 respondents $(62.5 \%)$ indicated that they were willing to be 91 vaccinated against COVID-19. Moreover, multivariable analysis revealed that HBM constructs 92 were associated with vaccination intention in the Philippines. Perceptions of high susceptibility, 93 high severity, and significant benefits were all good predictors for vaccination intent. We also 94 found that external cues to action were important. Large majorities of our respondents would only 95 receive the COVID-19 vaccines after many others had received it (72.8\%) or after politicians had 96 received it (68.2\%). Finally, our study revealed that most (21\%) were willing to pay an amount of 97 PHP1,000 [USD20] for the COVID-19 vaccines with an average willing-to-pay amount of 98 PHP1,892 [USD38]. Based on these findings, we inaugurated the UST-CoVAX public awareness 99 campaign that seeks to increase vaccine confidence in the Philippines by addressing the specific 
100 fears and concerns of our Filipino respondents and by sharing the personal vaccination testimonies 101 of Filipinos around the world.

102

103

104

105

106

107 108

109

110 111 old.

112

113

114

115

116

117

118

119

120

121 location of residence were collected. Participants were also asked if they have an existing chronic

\section{METHODS}

\section{Participants and Survey Design}

The current study design was a cross-sectional, anonymous, web-based survey—developed using Qualtrics-conducted from January 15, 2021 to January 29, 2021. Our research team deployed an anonymous link via the social platforms of the University of Santo Tomas (UST) like Twitter and Facebook and university mailing lists including the UST School of Science and UST Student Council to distribute the survey. Participants were encouraged to distribute the survey link to their contacts throughout the country. The questionnaire was written in both Filipino and English. Responses used for data collection were limited to respondents who were at least 18 years

\section{Survey Instrument}

The survey consisted of questions and statements that assessed the following: 1) demographics, health status, and COVID-19 experience, 2) intent to receive a COVID-19 vaccine;

3) perceived susceptibility to and severity of COVID-19; 4) perceived benefits of a COVID-19 vaccine; 5) willingness to pay (WTP) for a COVID-19 vaccine; and 6) confidence in COVID-19 vaccines made in other countries.

Demographics, health status, and COVID-19 experience: Demographic information including age, gender, marital status, education, occupation, monthly income, and urban or rural 
122 condition, if they ever tested positive for COVID-19, and to indicate if they know someone who

123 has tested positive for COVID-19.

124 Intent to receive a COVID-19 vaccine: Intention to receive a COVID-19 vaccine was 125 assessed using a one-item question ("If a vaccine for COVID-19 is available in the Philippines, 126 would you use it?') on a five-point scale ranging from $1=$ 'definitely no' to 5 = 'definitely yes'.

127 Responses were additionally recoded into two distinct categories: vaccine hesitant (responses 128 included: 'definitely no', 'probably no', and 'unsure') and not vaccine hesitant (responses 129 included: 'probably yes' and 'definitely yes').

130 Perceived susceptibility to and severity of COVID-19: HBM-derived items were used to 131 assess individual beliefs about a COVID-19 vaccine. Questions posed to participants assessed 132 perceived susceptibility of COVID-19 (two items), perceived severity of COVID-19 (three items), 133 and cues to action (two items). All response items were on a four-point scale ranging from 134 'strongly agree' to 'strongly disagree'. For analysis purposes, all responses were coded as either 135 'agree' (responses included: 'strongly agree' and 'agree') or 'disagree' (responses included: 136 'strongly disagree' and 'disagree').

137 Perceived benefits of a COVID-19 vaccine: Perceived benefits were queried using two 138 items. All response items were rated on a four-point scale ranging from 'strongly agree' to 139 'strongly disagree'. Similar to perceived susceptibility to and severity of COVID-19, all responses 140 were coded as either 'agree' or 'disagree'. In addition to perceived benefits of a COVID-19 141 vaccine, respondents were also asked to rate-on a four-point scale ranging from 'strongly agree' 142 to 'strongly disagree'-perceived barriers surrounding a COVID-19 vaccine (e.g., 'I worry about 143 the possible side-effects of the COVID-19 vaccine.'; 'I worry about fake COVID-19 vaccines.'). 144 For analysis purposes, all responses were coded as either 'agree' or 'disagree'. 
146 a one-item question ("What is the maximum amount you are willing to pay for two doses of the

147 COVID-19 vaccine?') on an eight-point scale ('PHP500', 'PHP1,000', 'PHP1,500', 'PHP2,000',

148 'PHP2,500', 'PHP3,000', 'PHP3,500', and 'PHP4,000'). The price range options were based on

149 the approximate minimum-maximum price range of current vaccines in the Philippines.

150 Confidence in an international COVID-19 vaccine: Participants were asked to rate their 151 level of confidence in using a vaccine for COVID-19 made in China, Russia, and the USA or

152 Europe on a four-point scale ('completely not confident', 'not confident', 'confident', and 153 'completely confident'). Preference for the nationality of a manufacturer of the COVID-19 vaccine 154 was also inquired.

155

156

\section{Ethics Review and IRB Approval}

158

160

161

162

163

164

165

166

167

\section{Statistical Analyses}

Our study protocol (Protocol Number 21-026) was reviewed and approved by the Institutional Review Board of Providence College on January 15, 2021. We had sought ethical review at the University of Santo Tomas in the Philippines but were advised by university authorities there to seek accelerated IRB approval in the United States because of the exigencies of the global pandemic. An informed consent statement was included in the survey instrument to welcome respondents who had clicked on the anonymous survey link provided by Qualtrics.

All statistical analyses were conducted using Statistical Package for the Social Sciences (SPSS) version 27. A p-value of less than .05 was considered statistically significant. Frequency 
168 tables, charts, and proportions were used for data summarization — proportions and their respective $16995 \%$ confidence intervals (CI) were calculated for each predictor variable. The model fit of binary 170 logistic regression analysis was calculated using the Hosmer-Lemeshow goodness-of-fit test

171 (Hosmer, Lemeshow \& Sturdivant, 2013). Participant responses to the one-item intent to receive 172 COVID-19 vaccine ('If a vaccine for COVID-19 is available in the Philippines, would you use 173 it?') was coded into two categories: vaccine hesitant (responses included: 'definitely no', 'probably 174 no', 'unsure') and not vaccine hesitant (responses included: 'probably yes', 'definitely yes'). The 175 eight options of WTP for a COVID-19 vaccine were categorized into three categories (PHP500176 1,000, PHP1,500-2,500, PHP3,000-4,000). A multinomial logistic regression was employed to 177 model factors associated with WTP for a COVID-19 vaccine with the lowest (PHP500-1,000) as 178 the reference. We ran univariate analyses followed by a binary logistic regression analysis, 179 including all factors showing significance $(p<.05)$, to determine which factors predicted 180 individual intention to receive a COVID-19 vaccine. Only significant factors in the univariate 181 analyses were included in the binary logistic regression analysis.

\section{RESULTS}

\section{Demographics}

A total of 7,193 complete survey responses were received. Responses received represented participants with diverse demographics as shown in Table 1, and from all of the regions of the

187 Philippines (Figure 1). The study sample had a higher representation of younger adults aged 18 to 188 30 years old $(52.4 \%)$, which is not unexpected given that our open access survey was deployed on social media. Additionally, the majority of participants identified as female $(66.6 \%)$, single 190 (65.7\%), had obtained a college/university degree or above (84\%), and lived in an urban location 
191 (78.9\%). Only a small portion of the sample reported having an existing chronic condition (16.4\%)

192 while $17.5 \%$ reported having either 'very poor', 'poor', or 'fair' health. Additionally, $72.8 \%$ of the 193 sample reported knowing someone who had tested positive for COVID-19.

194

195

196

197

198

199

200

201

202

203

204

205

206

207

208

209

210

211

\section{COVID-19 Vaccination Intent}

As displayed in Figure 2, with regards to perceived susceptibility to COVID-19 vaccines, the minority of participants reported that they thought that there was a high chance of personally contracting COVID-19 in the next few months (31.5\%). However, when prompted to report worry about the likelihood of getting COVID-19, the majority of participants reported that they were worried (84.1\%) and that COVID-19 is a serious illness with life-threatening conditions (96.3\%). Furthermore, a significant majority (93.1\%) reported that they were afraid of getting COVID-19, and that they would get very sick if they were infected with the virus (75\%). The respondents in the survey reported significant perceived benefits for the COVID-19 vaccines. A large portion of participants noted that they believed that a COVID-19 vaccine would decrease the chances of getting COVID-19 (88.1\%) and that the vaccine would alleviate their anxieties about catching the virus $(84.5 \%)$. Notably, significant majorities of our respondents reported that they had worries about possible side-effects (89.6\%), effectiveness (87.1\%), safety $(88.8 \%)$, and high cost $(78 \%)$ of the vaccines. Nearly all were concerned about the possibility of fake jabs (97.4\%). Many participants noted they would only receive the COVID-19 vaccines after many others had received it $(72.8 \%)$ or after politicians had received it $(68.2 \%)$. 
Figure 3 shows the proportion of responses for intention to take a COVID-19 vaccine if 214 one were available in the Philippines. A total of 4,497 of the participants $(62.5 \%)$ responded either 215 'probably yes' or 'definitely yes' to COVID-19 vaccine intent - demonstrating that they were not 216 vaccine hesitant-while 2,696 (37.4\%) displayed vaccine hesitancy (responses included 217 'definitely no', 'probably no', and 'unsure'). More specifically, the majority of responses were 218 'probably yes' $(32.8 \%, \mathrm{n}=2,358)$, followed by 'definitely yes' $(29.7 \%, \mathrm{n}=2,139)$, 'unsure' $(28 \%$, $219 \mathrm{n}=2,017)$, 'probably no' $(6.4 \%, \mathrm{n}=461)$, and 'definitely no' $(3 \%, \mathrm{n}=318)$. Demographics of 220 respondents who intend (not vaccine hesitant) and do not intend (vaccine hesitant) to take a 221 COVID-19 vaccine is displayed in Table 1.

222 Table 2 shows the univariate and binary analyses of factors associated with a vaccine 223 hesitant and a not vaccine hesitant intention by demographics and health belief constructs. 224 Univariate analyses showed a significantly higher proportion of participants who were single $225(63.6 \%)$ expressed an intention to take a COVID-19 vaccine (not vaccine hesitant) than married 226 participants $(60.4 \%)$. However, the association was not significant in the binary analysis. By 227 occupational category, a significantly higher proportion of respondents that were not vaccine 228 hesitant included those who identified as students $(65.5 \%)$ and professional/white collar workers $229(62 \%)$. Significant differences were noted in vaccine hesitancy for COVID-19 by location, 230 whereby individuals in an urban location (65\%) reported a higher proportion of an intention to 231 vaccinate compared to respondents in rural locations $(53.1 \%)$.

232 By demographics, binary analyses revealed that males have greater odds of an intention to 233 take a COVID-19 vaccine $(\mathrm{OR}=1.222,95 \% \mathrm{CI}[1.078-1.386])$ than females. Being self-employed $234(\mathrm{OR}=.776,95 \%$ CI $[.586-1.026])$, a student $(\mathrm{OR}=1.352,95 \%$ CI [1.046-1.749]), having a 235 monthly income of less than PHP10,000 (OR =.596, 95\% [CI, .477-.745]), PHP10,000-20,000 
$236(\mathrm{OR}=.587,95 \%$ CI [.465-.741] $)$, and PHP20,000-100,000 (OR = .822, 95\% CI [.679-.995]) were

237 also significant predictors of intent to vaccinate. Additionally, perceived overall health reported as

238 'fair', 'poor', and 'very poor' (OR =.755, 95\% CI [.632-.903]), and 'good' (OR = 1.173, 95\% CI

$239[1.024,1.343])$ were significant predictors of intent to vaccinate for COVID-19.

240 Most of the constructs of the HBM were significantly associated with an intention to take

241 a COVID-19 vaccination in the univariate analyses. While $72.8 \%$ of participants reported they

242 would only take the COVID-19 vaccine after many others receive it (Figure 3), disagreement with

243 that notion $(\mathrm{OR}=1.894,95 \%$ CI [1.597-2.247]) was the strongest predictor for an intent to

244 vaccinate. Intent to receive a COVID-19 vaccine only once politicians receive it (OR $=1.411,95 \%$

245 CI [1.214-1.640]) was also a strong predictor of intention to take a COVID-19 vaccine.

246

247 Willingness to Pay (WTP)

248 Table 3 shows that most participants were willing to pay PHP1,000 [USD20.38] (21\%)

249 followed by PHP500 [USD10.18] (18.8\%) for two doses of a COVID-19 vaccine. The median

250 (interquartile range [IQR]) of WTP for two doses of a COVID-19 vaccine was PHP2,000

251 [USD40.73]. Table 4 shows the results of the univariate and multinomial regression analyses for

252 the marginal WTP for an amount of PHP500/1,000 [USD10.18/20.36], PHP1,500/2,000/2,500

253 [USD30.55/40.73/50.91], PHP3000/3500/4000 [USD61.09/71.28/81.46] by demographics and

254 HBM constructs. The results of the multinomial logistic regression (PHP1,500/2,000/2,500 vs.

255 PHP500/1,000 and PHP3,000/3,500/4,000 vs. PHP500/1,000) revealed that individuals aged 31 to

25640 displayed a higher WTP: PHP3,000/3,500/4,000 [USD61.09/71.28/81.46] over PHP500/1,000

257 [USD10.18/20.36]. Compared to married participants, single respondents had the highest WTP:

258 PHP3,000/3,500/4,000 [USD61.09/71.28/81.46] over PHP500/1,000 [USD10.18/20.36]. Students 
259 had the highest WTP: PHP3,000/3,500/4,000 ([USD61.09/71.28/81.46] over PHP500/1,000

260 [USD10.18/20.36]. For monthly income, there was a gradual increase in the odds of WTP for an

261 amount PHP1,500/2,000/2,500 [USD30.55/40.73/50.91] over PHP500/1,000 [USD10.18/20.36].

262 Participants in rural locations were WTP: PHP1,500/2,000/2,500 [USD30.55/40.73/50.91] over

263 PHP500/1,000 [USD10.18/20.36]. For HBM constructs, similar to intent to vaccinate, a higher

264 WTP was significantly associated with items in the perceived susceptibility to and severity of 265 COVID-19, perceived benefits of a COVID-19 vaccine, perceived barriers, and cues to action 266 constructs.

267

268 Vaccine Brand Preference

269 Figure 4 shows confidence in foreign-made (i.e., China, Russia, and the USA or Europe)

270 COVID-19 vaccines. The vast majority of participants were 'confident' $(59.7 \%)$ or 'completely

271 confident' $(23.1 \%)$ in a COVID-19 vaccine made in the USA or Europe. In contrast, a majority of 272 participants indicated they were either 'completely not confident' $(38.2 \%, 16.5 \%)$ or 'not 273 confident' $(46.8 \%, 49.2 \%)$ in a vaccine developed in China and Russia respectively. Findings on 274 the preference of where a COVID-19 vaccine is made revealed respondents reported a preference 275 for a vaccine made in the USA or Europe $(53.4 \%)$ while $44.6 \%$ of participants indicated no 276 preference of where a COVID-19 vaccine is made as long as it is safe and effective.

277

278

\section{DISCUSSION}

279

In this study, we sought to interrogate the extent of COVID-19 vaccine hesitancy in the 280 Philippines and to determine whether the Health Belief Model (HBM) could be used to explain this hesitancy among Filipinos. We deployed our nationwide open-access online survey for a two 
282 week period (January 15-29, 2021), a month before the first COVID-19 vaccines were

283 administered in the archipelago on March 1, 2021.

284

We received nearly 7,200 completed surveys from around the country. The majority of

285 responses $(5,348 ; 74 \%)$ were from the three geographical and administrative regions, National

286 Capital Region (NCR), Region III, and Region IVA, that encompass and surround the capital city

287 of Manila. Together, these three regions, which have $38 \%$ of the population, have weathered the

288 worst of the COVID-19 pandemic in the Philippines with about $60 \%$ of the total nationwide

289 reported cases (ncovtracker.doh.gov.ph).

290 A majority of our respondents (62.5\%) indicated that they were willing to be vaccinated

291 by responding either 'probably yes' or 'definitely yes' to COVID-19 vaccine intent. As a point of

292 comparison, a survey conducted by Pulse Asia from February 22, 2021, to March 3, 2021, which

293 was a month after our survey period, reported that only $16 \%$ of the 2,400 Filipinos they interviewed

294 face-to-face indicated that they would have themselves vaccinated, while $23 \%$ said that they

295 "cannot say" if they would have themselves vaccinated (Pulse Asia, 2021).

296

There are many possible reasons for this difference in reported vaccine confidence but three

297

immediately come to mind. First, our survey was an open access online survey while the Pulse

Asia survey involved face-to-face interviews of Filipinos throughout the country. By their very

nature, online surveys are not representative of the population at large because access to the

internet is uneven, especially in developing countries. Second, the respondents of our survey were

skewed in favor of individuals living in those urban centers around the capital that have endured

the most stringent quarantine restrictions of the pandemic. It is likely that this pandemic experience 
305 innocuous. Notably, our bivariate analysis confirms that individuals in an urban location (65\%)

306 reported a higher proportion of an intention to vaccinate compared to respondents in rural locations

307 (53.1\%). Finally, the intervening month between the two surveys witnessed several political events

308 prior to the vaccine rollout that could have changed the public's views on the COVID-19 vaccines.

309 Most significantly, on February 26, 2021, President Rodrigo R. Duterte signed into law a bill

310 giving indemnity to vaccine makers should their vaccines cause serious adverse side effects among

311 recipients. The bill was criticized by several senators of the Philippines who described it as a

312 desperate move on the part of the Duterte administration to purchase untested vaccines on the

313 global market. This political squabble could have decreased public confidence in the safety of the

314 COVID-19 vaccines.

315 Multivariable analysis revealed that HBM constructs were associated with vaccination

316 intention in the Philippines, which is in accordance with other studies from the Asia-Pacific region

317 (Wong et al., 2020, 2021; Lin et al., 2020; Yu et al., 2021; Kabir et al., 2021; Huynh et al., 2021;

318 Tao, Wang \& Liu, 2021) Perceptions of high susceptibility, high severity, and significant benefits

319 were all good predictors for vaccination intent. A study to interrogate vaccine hesitancy among

320 Filipinos in two urban communities in Manila before the COVID-19 pandemic also found that

321 respondents who believed in the protective nature of vaccines were less likely to report vaccine

322 hesitancy and were nine times less likely to refuse vaccination for their children because of 323 negative media exposure (Migriño et al., 2020).

324 Perceived barriers against COVID-19 immunization reported by our respondents 325 including worries about the side-effects, effectiveness, and safety of the vaccines have also been 326 reported by these other HBM studies. These are triggers for hesitancy that can be eradicated with 327 scientific explanation. Public health authorities in the Philippines should address these issues. In 
328 response to the findings of this survey, we have initiated a public awareness campaign in the

329 Philippines to directly respond to these concerns by generating infographics and other publication

330 materials to alleviate these worries (https://www.facebook.com/USTCoVAX/).

331 Interestingly, we discovered that our Filipino respondents were overwhelmingly worried

332 about fake COVID-19 vaccines (97.4\%). This is not surprising given the prevalence of counterfeit

333 items in Philippine society (Calunsod 2013). Similar concerns have been raised in India

334 (Choudhary et al., 2021) though this was not observed in China (Lin et al., 2020). This suggests

335 that the national governments of developing countries should ensure the integrity of the vaccine

336 rollout to reassure their citizens that they are not receiving "dud" doses.

337 Next, we found that external cues to action were important. Large majorities of our

338 respondents would only receive the COVID-19 vaccines after many others had received it (72.8\%)

339 or after politicians had received it $(68.2 \%)$. We observed that disagreement with the statement that

340 the individual would receive the COVID-19 vaccine only after many others had received it was

341 the strongest predictor for an intent to vaccinate among our Filipino respondents. This segment of

342 the population could represent citizens who so want to be vaccinated that they are willing to put

343 aside the collectivist mindset that is strongly rooted in Filipino culture (Grimm et al., 1999).

344 However, given the high numbers of respondents who indicated that they were waiting for others

345 to first receive the vaccine, our UST-CoVAX public awareness program began sharing the

346 personal vaccination testimonies of Filipinos around the world on social media platforms to show

347 Filipinos in the Philippines that others like them had already received the COVID-19 vaccines 348 (https://www.facebook.com/USTCoVAX/).

349 Our study revealed that most (21\%) were willing to pay an amount of PHP1,000 [USD20]

350 for two doses of the COVID-19 vaccines with an average willing-to-pay amount of PHP1,892 
351 [USD38]. Multinomial logistic regression showed that individuals aged 31 to 40, single

352 respondents, and students had the highest WTP in their demographic categories respectively. Since

353 the minimum daily wage in the Philippines in 2021 is PHP537 [USD10.54], the average WTP

354 amount of PHP1,892 [USD38] remains a significant investment in the health of the individual,

355 equivalent to nearly four days of wages. This suggests that the COVID-19 vaccines should be

356 provided free of charge to ensure population-wide access among all Filipinos across the economic 357 classes.

358 Finally, our analysis revealed significant vaccine brand preference among our Filipino 359 respondents. The vast majority of participants were 'confident' (59.7\%) or 'completely confident'

$360(23.1 \%)$ in a COVID-19 vaccine made in the USA or Europe. In contrast, a majority of participants

361 indicated they were either 'completely not confident' $(38.2 \%, 16.5 \%)$ or 'not confident' $(46.8 \%$,

$36249.2 \%$ ) in a vaccine developed in China and Russia respectively. These findings mirror those

363 reported by the Pulse Asia survey already described above that showed that a majority (52\%) of 364 Filipinos who were opting to get vaccinated preferred the Pfizer vaccine (Pulse Asia, 2021). The

365 roots of this brand preference are not clear. One possibility could be the political controversy in 366 the Philippine Senate where senators deemed the Chinese vaccine brands "unacceptable" because 367 of their low efficacy (Romero 2020). Anecdotally, Filipino social media influencers have also 368 reminded Filipinos of the contaminated Chinese milk products that had been banned in the 369 Philippines over a decade ago (Crisostomo 2012). Regardless of the reasons, this vaccine 370 preference has to be managed by the national government to prevent Filipinos from unnecessarily 371 delaying immunization to obtain their preferred vaccine brand.

373 online survey may result in sampling bias so we cannot generalize our findings to the entire 
374 Filipino population (Wyatt, 2000; Eysenbach \& Wyatt, 2002). It is notable that young people aged 375 18-30 years, who make up around $28 \%$ of the population of the Philippines 376 (https://www.populationpyramid.net/philippines/), constitute $52.4 \%$ of our respondents. 377 Unexpectedly, however, senior citizens aged 61-89 years of age, who constitute $8 \%$ of the 378 country's population are also over-represented with $11.8 \%$ of the respondents. Furthermore, the 379 responses were based on self-report and may be subject to self-reporting bias and a tendency to 380 report socially desirable responses especially in a strongly collectivist society like the Philippines.

381 One final limitation of our study is the bias associated with the assessment of acceptance and WTP 382 for a hypothetical COVID-19 vaccine before any concrete vaccines actually exist (Schmidt \& 383 Bijmolt, 2019). We therefore intend to undertake a follow-up survey once the vaccine rollout in 384 the country has stabilized. Nonetheless, despite these shortcomings, we believe that our findings 385 will provide insights to support the vaccine rollout of the COVID-19 vaccines in the Philippines 386 by helping public health authorities to understand vaccine demand and vaccine hesitancy in the 387 country. Indeed, based on these findings, we inaugurated the UST-CoVAX public awareness 388 campaign that seeks to increase vaccine confidence in the Philippines by addressing the specific 389 fears and concerns of our Filipino respondents and by sharing the personal vaccination testimonies 390 of Filipinos around the world. (https://www.facebook.com/USTCoVAX/). 


\section{REFERENCES}

394 Alfonso C., Dayrit M., Mendoza R., Ong M. 2021. From Dengvaxia to Sinovac: Vaccine $395 \quad$ Hesitancy in the Philippines. The Diplomat.

396 Banik R., Islam MS., Pranta MUR., Rahman QM., Rahman M., Pardhan S., Driscoll R., Hossain 397 S., Sikder MT. 2021. Understanding the determinants of COVID-19 vaccination intention and willingness to pay: findings from a population-based survey in Bangladesh. $B M C$ Infectious Diseases 21:892. DOI: 10.1186/s12879-021-06406-y.

401

Brewer NT., Chapman GB., Gibbons FX., Gerrard M., McCaul KD., Weinstein ND. 2007. Metaanalysis of the relationship between risk perception and health behavior: The example of

402 vaccination. Health Psychology 26:136-145. DOI: 10.1037/0278-6133.26.2.136.

403

404

405

406

407

408

409

410

411

412

413

414

415

Burki T. 2020. Outbreak of coronavirus disease 2019. Lancet Infect Dis 20:292-293.

Calunsod, Ronron. 2013. “Counterfeiting, Piracy Remain Rampant in Philippines | ABS-CBN News.” ABS-CBN News. 2013. https://news.abs-cbn.com/focus/06/14/13/counterfeitingpiracy-remain-rampant-philippines.

Case JB., Winkler ES., Errico JM., Diamond MS. 2021. On the road to ending the COVID-19 pandemic: Are we there yet? Virology 557:70-85. DOI: 10.1016/j.virol.2021.02.003.

Chen IH., Hsu SM., Wu JSJ., Wang YT., Lin YK., Chung MH., Huang PH., Miao NF. 2019. Determinants of nurses' willingness to receive vaccines: Application of the health belief model. Journal of Clinical Nursing 28:3430-3440. DOI: 10.1111/jocn.14934.

Choudhary OP., Priyanka., Singh I., Mohammed TA., Rodriguez-Morales AJ. 2021. Fake COVID-19 vaccines: scams hampering the vaccination drive in India and possibly other countries. Human Vaccines and Immunotherapeutics. DOI: 
416 Crisostomo, Sheila. 2012. "FDA: No Imported Chinese Milk Products in PH | ABS-CBN News."

417 The Philippine Star. 2012. https://news.abs-cbn.com/lifestyle/06/20/12/fda-no-imported-

418 chinese-milk-products-ph.

419 Donadiki EM., Jiménez-García R., Hernández-Barrera V., Sourtzi P., Carrasco-Garrido P.,

420 López de Andrés A., Jimenez-Trujillo I., Velonakis EG. 2014. Health Belief Model applied

421 to non-compliance with HPV vaccine among female university students. Public Health

422 128:268-273. DOI: 10.1016/j.puhe.2013.12.004.

423 Eysenbach G., Wyatt J. 2002. Using the Internet for surveys and health research. Journal of

424 Medical Internet Research 4:76-94. DOI: 10.2196/JMIR.4.2.E13.

425 Fatima, Khunsha, and Najah Irfan Syed. 2018. "Dengvaxia Controversy: Impact on Vaccine

426 Hesitancy." Journal of Global Health 8 (2). https://doi.org/10.7189/JOGH.08-020312.

427 Grimm SD., Church AT., Katigbak MS., Reyes JA. 1999. Self-Described Traits, Values, and

428 Moods Associated with Individualism and Collectivism Testing I-C Theory in an

429 Individualistic (U.S.) and a Collectivistic (Philippine) Culture. Journal of Cross-Cultural

$430 \quad$ Psychology 30:466-500.

431 Guan WJ., Ni ZY., Hu Y., Liang WH., Ou CQ., He JX., Liu L., Shan H., Lei CL., Hui DSC., Du

432 B., Li LJ., Zeng G., Yuen KY., Chen RC., Tang CL., Wang T., Chen PY., Xiang J., Li SY.,

433 Wang JL., Liang ZJ., Peng YX., Wei L., Liu Y., Hu YH., Peng P., Wang JM., Liu JY.,

434 Chen Z., Li G., Zheng ZJ., Qiu SQ., Luo J., Ye CJ., Zhu SY., Zhong NS. 2020. Clinical

435 Characteristics of Coronavirus Disease 2019 in China. The New England journal of

436 medicine 382:1708-1720. DOI: 10.1056/NEJMoa2002032.

437 Hosmer DWJ., Lemeshow S., Sturdivant R. 2013. Applied Logistic Regression. Hoboken, NJ:

$438 \quad$ John Wiley \& Sons, Inc. 
439 Hu Y., Wang Y., Liang H., Chen Y. 2017. Seasonal influenza vaccine acceptance among 440 pregnant women in zhejiang province, china: Evidence based on health belief model.

441

442

443

444

445

446

447

448

449

450

451

452

453

454

455

456

457

458

459

460

461

International Journal of Environmental Research and Public Health 14. DOI: 10.3390/ijerph14121551.

Huynh G., Nguyen HTN., Nguyen VT., Pham A Le. 2021. Development and Psychometric Properties of the Health Belief Scales Toward COVID-19 Vaccine in Ho Chi Minh City, Vietnam. Risk management and healthcare policy 14:2517-2526. DOI: 10.2147/RMHP.S301645.

Inter-Agency Task Force for the Management of Emerging Infectious Disease. 2021. The Philippine National COVID-19 Vaccination Deployment Plan | Department of Health website.

Kabir R., Mahmud I., Chowdhury MTH., Vinnakota D., Jahan SS., Siddika N., Isha SN., Nath SK., Hoque Apu E. 2021. COVID-19 Vaccination Intent and Willingness to Pay in Bangladesh: A Cross-Sectional Study. Vaccines 9. DOI: 10.3390/vaccines9050416.

Lin Y., Hu Z., Zhao Q., Alias H., Danaee M., Wong LP. 2020. Understanding COVID-19 vaccine demand and hesitancy: A nationwide online survey in China. PLoS neglected tropical diseases 14:e0008961. DOI: 10.1371/journal.pntd.0008961.

Mahmud I., Kabir R., Rahman MA., Alradie-Mohamed A., Vinnakota D., Al-Mohaimeed A. 2021. The health belief model predicts intention to receive the covid-19 vaccine in saudi arabia: Results from a cross-sectional survey. Vaccines 9. DOI: 10.3390/vaccines9080864.

Migriño J., Gayados B., Birol KRJ., De Jesus L., Lopez CW., Mercado WC., Tolosa JMC., Torreda J., Tulagan G. 2020. Factors affecting vaccine hesitancy among families with children 2 years old and younger in two urban communities in Manila, Philippines. Western 
462

463

464 Novelli G., Biancolella M., Mehrian-Shai R., Colona VL., Brito AF., Grubaugh ND., Vasiliou

465 V., Luzzatto L., Reichardt JKV. 2021. COVID-19 one year into the pandemic: from

466

467

468

469

470

471

472

473

474

475

476

477

478

479

480

481 Vaccines in the United States: a systematic review on history of evolution, regulations, 482 licensing, and future challenges. Clinical and experimental vaccine research 9:69-75. DOI:

483

484

Pacific surveillance and response journal : WPSAR 11:20-26. DOI:

10.5365/wpsar.2019.10.2.006. V., Luzzatto L., Reichardt JKV. 2021. COVID-19 one year into the pandemic. from genetics and genomics to therapy, vaccination, and policy. Human Genomics 15. DOI: 10.1186/s40246-021-00326-3.

Paules C., Marston H., Fauci A. 2020. Coronavirus infections-more than just the common cold. JAMA 323:707.

Pulse Asia. 2021.February 2021 Nationwide Survey on COVID-19. Available at https://www.pulseasia.ph/february-2021-nationwide-survey-on-covid-19/

Rappuoli R., Pizza M., Del Giudice G., De Gregorio E. 2014. Vaccines, new opportunities for a new society. Proceedings of the National Academy of Sciences of the United States of America 111:12288-12293. DOI: 10.1073/pnas.1402981111.

Romero, Paolo. 2020. “Senators: 50\% Sinovac Efficacy Unacceptable | Philstar.Com.” The Philippine Star. 2020. https://www.philstar.com/headlines/2020/12/26/2066273/senators50-sinovac-efficacy-unacceptable.

Rosenstock IM., Strecher VJ., Becker MH. 1988. Social Learning Theory and the Health Belief Model. Health Education \& Behavior 15:175-183. DOI: 10.1177/109019818801500203.

Sathyanarayana SD., Fernandes SD., Castelino LJ., Vadakkepushpakath AN., Shriram RG. 2020. 10.7774/cevr.2020.9.2.69.

Schmidt J., Bijmolt THA. 2019. Accurately measuring willingness to pay for consumer goods: a 
485

486

487

488

489

490

491

492

493

494

495

496

497

498

499

500

501

502

503

504

505

506

507

meta-analysis of the hypothetical bias. Journal of the Academy of Marketing Science 2019 48:3 48:499-518. DOI: 10.1007/S11747-019-00666-6.

Shahrabani S., Benzion U. 2010. Workplace vaccination and other factors impacting influenza vaccination decision among employees in Israel. International Journal of Environmental Research and Public Health 7:853-869. DOI: 10.3390/ijerph7030853.

Shahrabani S., Benzion U., Yom Din G. 2009. Factors affecting nurses' decision to get the flu vaccine. European Journal of Health Economics 10:227-231. DOI: 10.1007/s10198-0080124-3.

Shmueli L. 2021. Predicting intention to receive COVID-19 vaccine among the general population using the health belief model and the theory of planned behavior model. $B M C$ public health 21:804. DOI: 10.1186/S12889-021-10816-7.

Smith, Nicola. 2018. "Philippines Immunisation Rates Plummet amid Dengue Vaccination Scare.” The Telegraph, 2018. https://www.telegraph.co.uk/news/2018/02/05/philippinesimmunisation-rates-plummet-amid-dengue-vaccination/.

Tao L., Wang R., Liu J. 2021. Comparison of Vaccine Acceptance Between COVID-19 and Seasonal Influenza Among Women in China: A National Online Survey Based on Health Belief Model. Frontiers in medicine 8:679520. DOI: 10.3389/fmed.2021.679520.

Teitler-Regev S., Shahrabani S., Benzion U. 2011. Factors Affecting Intention among Students to Be Vaccinated against A/H1N1 Influenza: A Health Belief Model Approach. Advances in Preventive Medicine 2011:1-8. DOI: 10.4061/2011/353207.

Tsutsui Y., Benzion U., Shahrabani S. 2012. Economic and behavioral factors in an individual's decision to take the influenza vaccination in Japan. Journal of Socio-Economics 41:594602. DOI: $10.1016 /$ j.socec.2012.05.001. 
508 Wong LP., Alias H., Wong PF., Lee HY., AbuBakar S. 2020. The use of the health belief model

509 to assess predictors of intent to receive the COVID-19 vaccine and willingness to pay.

510 Human Vaccines and Immunotherapeutics 16:2204-2214. DOI:

$511 \quad 10.1080 / 21645515.2020 .1790279$.

512 Wong MCS., Wong ELY., Huang J., Cheung AWL., Law K., Chong MKC., Ng RWY., Lai

513 CKC., Boon SS., Lau JTF., Chen Z., Chan PKS. 2021. Acceptance of the COVID-19

$514 \quad$ vaccine based on the health belief model: A population-based survey in Hong Kong.

$515 \quad$ Vaccine 39:1148-1156. DOI: 10.1016/j.vaccine.2020.12.083.

516 Wyatt JC. 2000. When to use web-based surveys. Journal of the American Medical Informatics

517 Association 7:426-430. DOI: 10.1136/jamia.2000.0070426.

518 Xie J., Tong Z., Guan X., Du B., Qiu H. 2020. Clinical Characteristics of Patients Who Died of 519 Coronavirus Disease 2019 in China. JAMA network open 3:e205619. DOI:

$520 \quad$ 10.1001/jamanetworkopen.2020.5619.

521 Yu Y., Lau JTF., She R., Chen X., Li L., Li L., Chen X. 2021. Prevalence and associated factors 522 of intention of COVID-19 vaccination among healthcare workers in China: application of

523 the Health Belief Model. Human Vaccines and Immunotherapeutics. DOI:

$524 \quad 10.1080 / 21645515.2021 .1909327$.

525 Zhu N., Zhang D., Wang W., al. et. 2020. A novel coronavirus from patients with pneumonia in 526 China, 2019. N Engl J Med 382:727-733.

527

528 
Figure 1

Geographical Distribution of Responses to our Online Survey

\begin{tabular}{|c|c|c|}
\hline $\begin{array}{l}\text { REGION OF THE } \\
\text { PHILIPPINES }\end{array}$ & $\begin{array}{l}\text { Number of } \\
\text { Responses } \\
\text { (n) }\end{array}$ & $\begin{array}{c}\text { Percent of } \\
\text { Responses } \\
(\%)\end{array}$ \\
\hline BARMM & 15 & $0.2 \%$ \\
\hline CAR & 41 & $0.6 \%$ \\
\hline NCR & 3,602 & $50.1 \%$ \\
\hline Region I & 131 & $1.8 \%$ \\
\hline Region II & 125 & $1.7 \%$ \\
\hline Region III & 722 & $10 \%$ \\
\hline Region IV-A & 1,024 & $14.2 \%$ \\
\hline Region IV-B & 56 & $0.8 \%$ \\
\hline Region IX & 52 & $0.7 \%$ \\
\hline Region V & 92 & $1.3 \%$ \\
\hline Region VI & 456 & $6.3 \%$ \\
\hline Region VII & 504 & $7 \%$ \\
\hline Region VIII & 85 & $1.2 \%$ \\
\hline Region X & 141 & $2 \%$ \\
\hline Region XI & 79 & $1.1 \%$ \\
\hline Region XII & 41 & $0.6 \%$ \\
\hline Region XIII & 14 & $0.2 \%$ \\
\hline No Region Listed & 13 & $0.2 \%$ \\
\hline
\end{tabular}

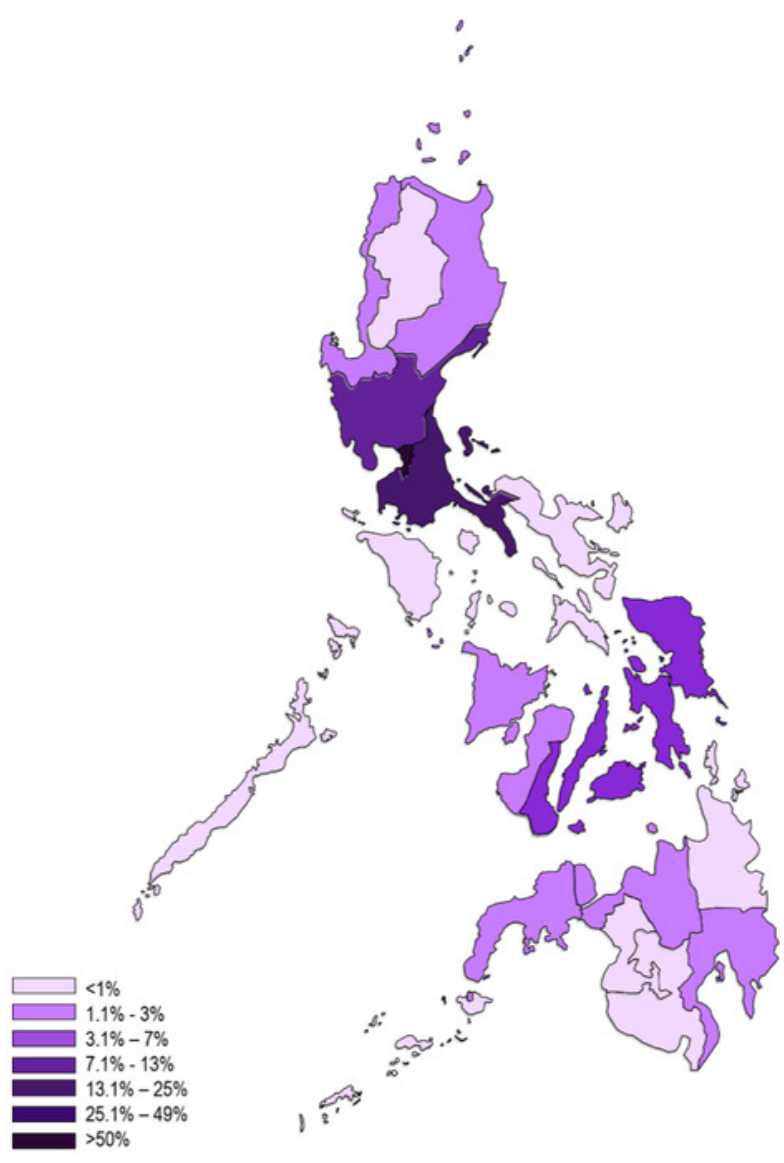


Figure 2

\section{Respondents' Health Beliefs Regarding COVID-19 and its Vaccines}

Respondents' Health Beliefs Regarding COVID-19 and its Vaccines

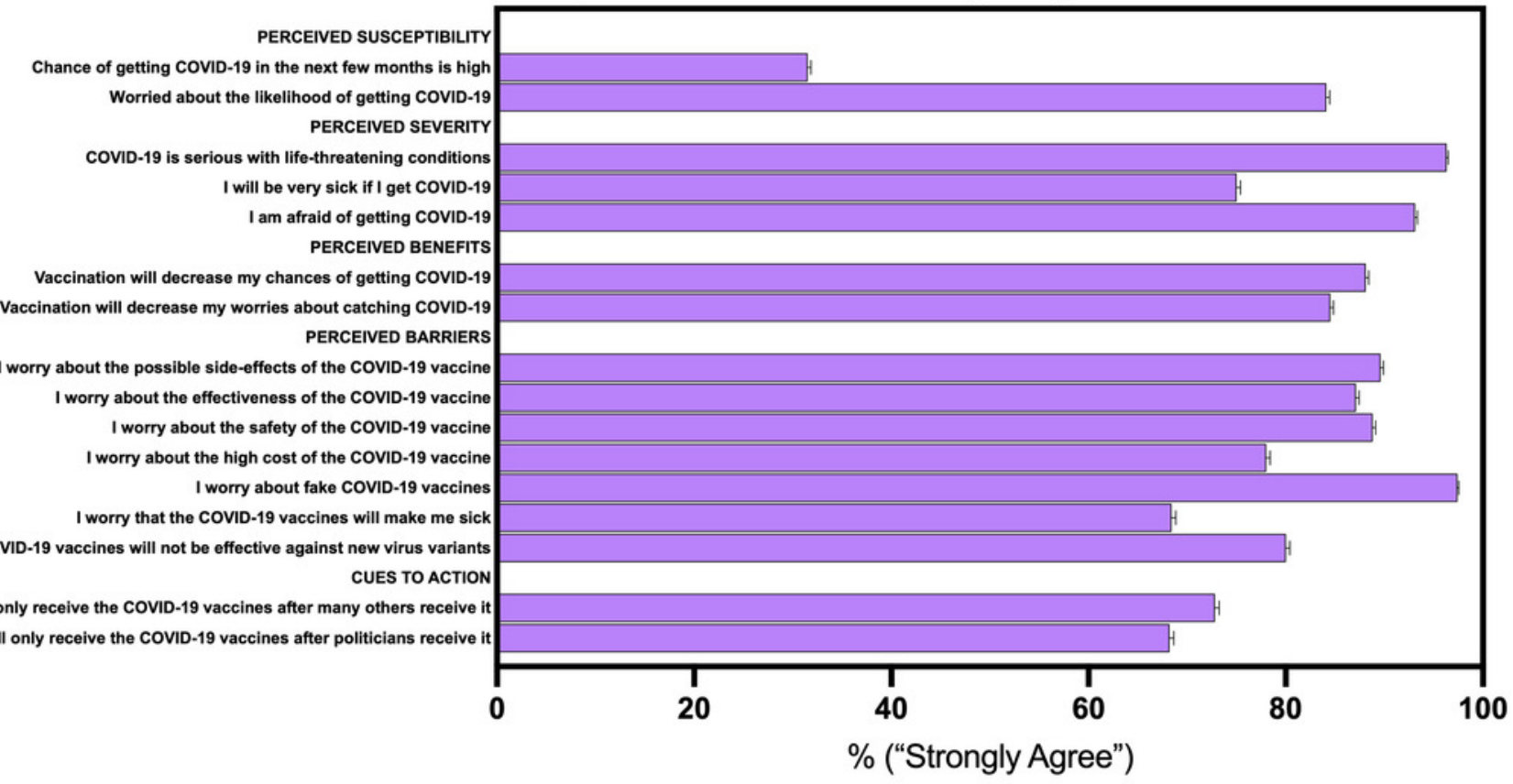


Figure 3

COVID-19 Vaccination Intent 


\section{COVID-19 Vaccination Intent $(n=7,193)$}

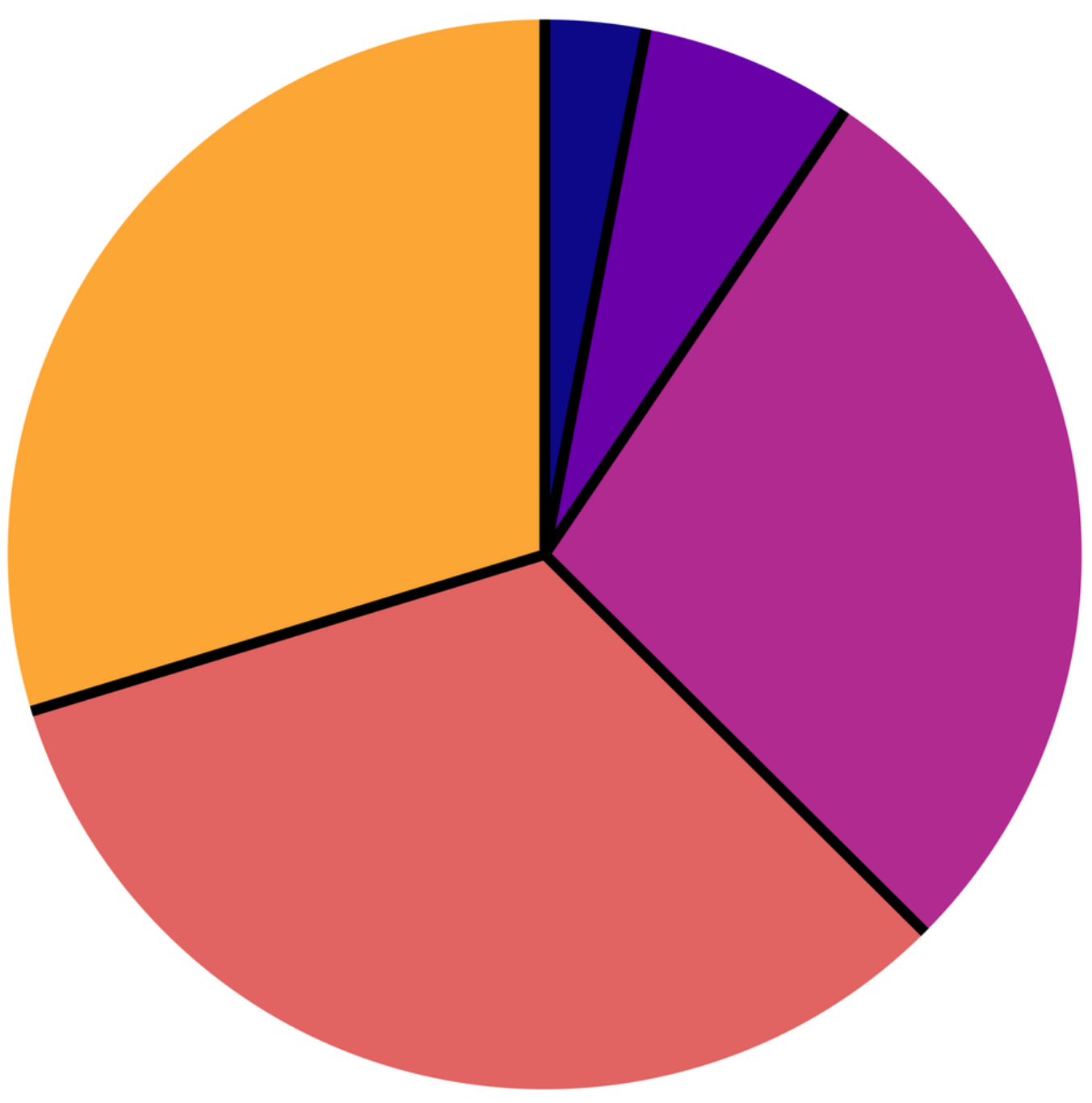

Definitely No ( $\mathrm{n}=218 ; 3 \%)$

Probably No $(n=461 ; 6.4 \%)$

Unsure ( $n=2,017 ; 28 \%)$

Probably Yes ( $n=2,358 ; 32.8 \%)$

Definitely Yes ( $n=2,139 ; 29.7 \%)$ 


\section{Figure 4}

Confidence in Foreign-made COVID-19 Vaccines

\section{Confidence in a Russian Vaccine} $(n=7,913)$

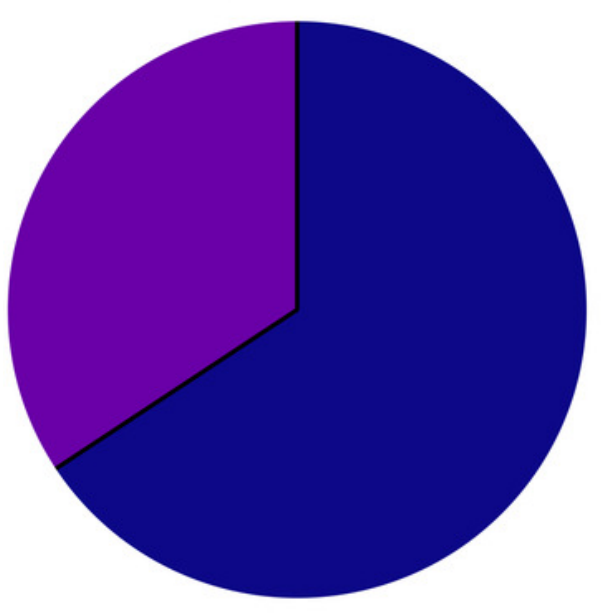

Not Confident ( $n=4,726 ; 65.7 \%)$

Confident $(n=2,467 ; 34.3 \%)$
Confidence in a Chinese Vaccine $(n=7,193)$

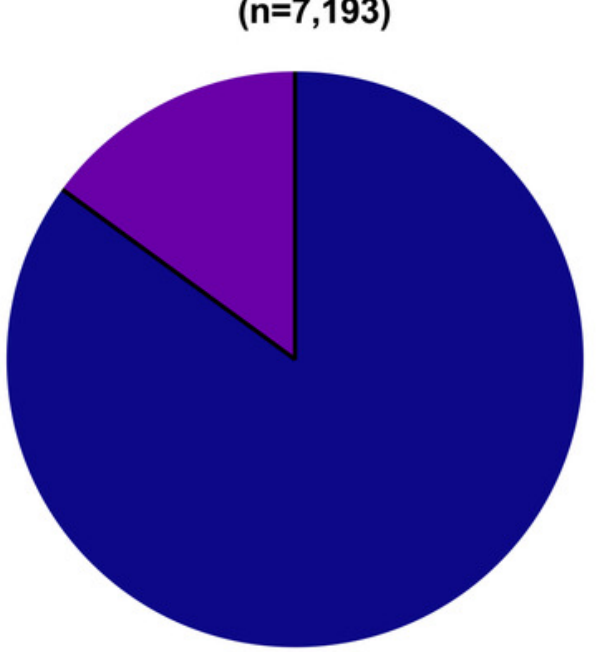

Not Confident $(\mathrm{n}=6,118 ; 85 \%)$

Confident $(n=1,075 ; 15 \%)$

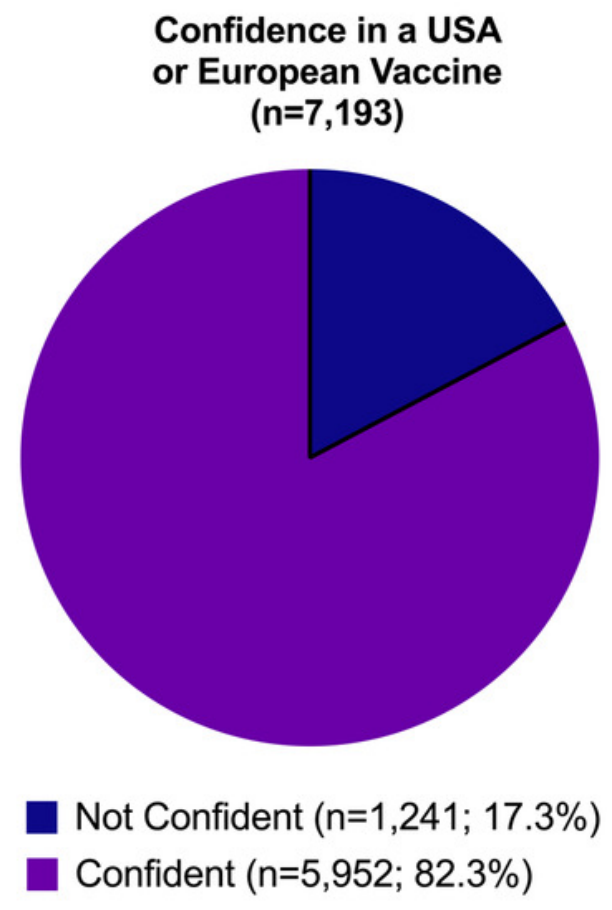

Confidence in a USA $(n=7,193)$

Not Confident $(n=1,241 ; 17.3 \%)$

Confident ( $n=5,952 ; 82.3 \%)$ 
Table $\mathbf{1}$ (on next page)

Demographics and COVID-19 Vaccine intent $(N=7,193)$ 
2

\begin{tabular}{|c|c|c|c|}
\hline & \multirow[b]{2}{*}{ Overall N (\%) } & \multicolumn{2}{|c|}{$\begin{array}{l}\text { If a vaccine for COVID-19 is available in the Philippines, would } \\
\text { you use it? }\end{array}$} \\
\hline & & $\begin{array}{c}\text { Vaccine hesitant } \\
\text { (Definitely no/Probably } \\
\text { no/Unsure) } \\
\mathrm{n}=2696(\%)\end{array}$ & $\begin{array}{c}\text { Not vaccine hesitant } \\
\text { (Probably yes/Definitely } \\
\text { yes) } \\
\mathrm{n}=4497(\%)\end{array}$ \\
\hline \multicolumn{4}{|l|}{ Demographics } \\
\hline \multicolumn{4}{|l|}{ Age group (years) } \\
\hline $18-30$ & $3770(52.4)$ & $1405(37.3)$ & $2365(62.7)$ \\
\hline $31-40$ & $815(11.3)$ & $306(37.5)$ & $509(62.5)$ \\
\hline $41-50$ & $861(12)$ & $335(38.9)$ & $526(61.1)$ \\
\hline $51-60$ & $900(12.5)$ & $326(36.2)$ & $574(63.8)$ \\
\hline $61-89$ & $847(11.8)$ & $324(38.3)$ & $523(61.7)$ \\
\hline \multicolumn{4}{|l|}{ Gender } \\
\hline Female & $4789(66.6)$ & $1955(40.8)$ & $2834(59.2)$ \\
\hline Male & $2404(33.4)$ & $741(30.8)$ & $1663(69.2)$ \\
\hline \multicolumn{4}{|l|}{ Marital Status } \\
\hline Single & $4724(65.7)$ & $1719(36.4)$ & $3005(63.6)$ \\
\hline Married & $2469(34.3)$ & $977(39.6)$ & $1492(60.4)$ \\
\hline \multicolumn{4}{|l|}{ Highest Education Level } \\
\hline Elementary school or below & 1 & 1 & \\
\hline Junior high school & $46(.6)$ & $29(63)$ & $17(37)$ \\
\hline Senior high school & $1102(15.3)$ & $378(34.3)$ & $724(65.7)$ \\
\hline College/university of above & $6044(84)$ & $2288(37.9)$ & $3756(62.1)$ \\
\hline \multicolumn{4}{|l|}{ Occupation } \\
\hline Blue collar worker & $91(1.3)$ & $42(46.2)$ & $49(53.8)$ \\
\hline Profession/white collar worker & $2980(41.4)$ & $1133(38)$ & $1847(62)$ \\
\hline Self-employed & $575(8)$ & $254(44.2)$ & $321(55.8)$ \\
\hline Student & $2831(39.4)$ & $976(34.5)$ & $1855(65.5)$ \\
\hline Housewife/retired/unemployed/other & $716(10)$ & $291(40.6)$ & $425(59.4)$ \\
\hline \multicolumn{4}{|l|}{ Monthly Income (PHP) } \\
\hline$\leq 10,000$ & $2583(35.9)$ & $1004(38.9)$ & $1579(61.1)$ \\
\hline $10,000-20,000$ & $954(13.3)$ & $468(49.1)$ & $486(50.9)$ \\
\hline $20,000-100,000$ & $2517(35)$ & $907(36)$ & $1610(64)$ \\
\hline$\geq 100,000$ & $1139(15.8)$ & $317(27.8)$ & $822(72.2)$ \\
\hline \multicolumn{4}{|l|}{ Location } \\
\hline Urban & $5676(78.9)$ & $1985(35)$ & $3691(65)$ \\
\hline Rural & $1517(21.1)$ & $711(46.9)$ & $806(53.1)$ \\
\hline \multicolumn{4}{|l|}{ Ever tested positive for COVID-19 } \\
\hline Yes & $211(2.9)$ & $68(32.2)$ & $143(67.8)$ \\
\hline No & $6982(97.1)$ & $2628(37.6)$ & $4354(62.4)$ \\
\hline $\begin{array}{l}\text { Know anyone who has tested positive for } \\
\text { COVID-19 }\end{array}$ & & & \\
\hline
\end{tabular}




\begin{tabular}{|l|c|c|c|}
\hline Yes & $5234(72.8)$ & $1780(34)$ & $3454(66)$ \\
\hline No & $1959(27.2)$ & $916(46.8)$ & $1043(53.2)$ \\
\hline Have an existing chronic condition & & & \\
\hline Yes & $1178(16.4)$ & $396(33.6)$ & $782(66.4)$ \\
\hline No & $6015(83.6)$ & $2300(38.2)$ & $3715(61.8)$ \\
\hline Perceived overall health & & & \\
\hline Very good & $1997(27.8)$ & $802(40.2)$ & $1195(59.8)$ \\
\hline Good & $3934(54.7)$ & $1376(35)$ & $2558(65)$ \\
\hline Fair/Poor/Very poor & $1262(17.5)$ & $518(41)$ & $744(59)$ \\
\hline
\end{tabular}

3

4

5 
Table 2 (on next page)

Demographics, Characteristics, and Factors associated with an Intention to take the COVID-19 Vaccine $(N=7,193)$ 
1

2

3

Table 2. Demographics, Characteristics, and Factors associated with an Intention to take the COVID-19 Vaccine $(N=7,193)$

\begin{tabular}{|c|c|c|c|c|c|c|c|}
\hline & & \multicolumn{3}{|c|}{ Univariable analysis } & \multirow[b]{2}{*}{$p$-value } & \multirow{2}{*}{$\begin{array}{c}\text { Multivariable } \\
\text { logistic regression }\end{array}$} & \multirow[b]{2}{*}{$p$-value } \\
\hline & $\begin{array}{l}\text { Overall } \\
\text { N (\%) }\end{array}$ & $\begin{array}{c}\text { Vaccine } \\
\text { hesitant } \\
\mathrm{n}=2696\end{array}$ & $\begin{array}{c}\text { Not } \\
\text { vaccine } \\
\text { hesitant } \\
\mathrm{n}=4497\end{array}$ & $\begin{array}{c}\text { Unadjusted } \\
\text { OR }[95 \% \\
\text { CI }]\end{array}$ & & & \\
\hline \multicolumn{8}{|l|}{ Demographics } \\
\hline \multicolumn{8}{|l|}{ Age group (years) } \\
\hline $18-30$ & $\begin{array}{l}3770 \\
(52.4) \\
\end{array}$ & $\begin{array}{l}1405 \\
(37.3) \\
\end{array}$ & $\begin{array}{l}2365 \\
(62.7) \\
\end{array}$ & Reference & & & \\
\hline $31-40$ & $\begin{array}{l}815 \\
(11.3) \\
\end{array}$ & $306(37.5)$ & $509(62.5)$ & $\begin{array}{l}1.043[.894, \\
1.216] \\
\end{array}$ & .800 & & \\
\hline $41-50$ & $\begin{array}{l}861 \\
(12) \\
\end{array}$ & $335(38.9)$ & $526(61.1)$ & $1.030[8.45$ & & & \\
\hline $51-60$ & $\begin{array}{l}900 \\
(12.5) \\
\end{array}$ & $326(36.2)$ & $574(63.8)$ & $\begin{array}{l}.973[.800, \\
1.182] \\
\end{array}$ & & & \\
\hline $61-89$ & $\begin{array}{l}847 \\
(11.8) \\
\end{array}$ & $324(38.3)$ & $523(61.7)$ & $\begin{array}{l}1.091[.898, \\
1.324] \\
\end{array}$ & & & \\
\hline \multicolumn{8}{|l|}{ Gender } \\
\hline Female & $\begin{array}{l}4789 \\
(66.6) \\
\end{array}$ & $\begin{array}{l}1955 \\
(40.8) \\
\end{array}$ & $\begin{array}{l}2834 \\
(59.2) \\
\end{array}$ & $\begin{array}{l}.646[.582, \\
.717]\end{array}$ & $<.001$ & Reference & \\
\hline Male & $\begin{array}{l}2404 \\
(33.4) \\
\end{array}$ & $741(30.8)$ & $\begin{array}{l}1663 \\
(69.2) \\
\end{array}$ & & & $1.223[1.078,1.386]$ & .002 \\
\hline \multicolumn{8}{|l|}{ Marital Status } \\
\hline Single & $\begin{array}{l}4724 \\
(65.7) \\
\end{array}$ & $\begin{array}{l}1719 \\
(36.4) \\
\end{array}$ & $\begin{array}{l}3005 \\
(63.6) \\
\end{array}$ & & & $1.098[.939,1.286]$ & .242 \\
\hline Married & $\begin{array}{l}2469 \\
(34.3) \\
\end{array}$ & $977(39.6)$ & $\begin{array}{l}1492 \\
(60.4) \\
\end{array}$ & $\begin{array}{l}.874[.790, \\
.966] \\
\end{array}$ & .008 & Reference & \\
\hline \multicolumn{8}{|l|}{ Highest Education Level } \\
\hline Elementary school or below & 1 & 1 & \multicolumn{5}{|c|}{$n$ too small to calculate } \\
\hline Junior high school & $46(.6)$ & $29(63)$ & $17(37)$ & $\begin{array}{l}2.80[1.535, \\
5.107]\end{array}$ & $<.001$ & $.465[.234, .924]$ & .029 \\
\hline Senior high school & $\begin{array}{l}1102 \\
(15.3) \\
\end{array}$ & $378(34.3)$ & $724(65.7)$ & $\begin{array}{l}.857[.749, \\
.981] \\
\end{array}$ & & $1.064[.886,1.277]$ & .506 \\
\hline College/university of above & $\begin{array}{l}6044 \\
(84) \\
\end{array}$ & $\begin{array}{l}2288 \\
(37.9) \\
\end{array}$ & $\begin{array}{l}3756 \\
(62.1) \\
\end{array}$ & Reference & & Reference & \\
\hline \multicolumn{8}{|l|}{ Occupation } \\
\hline Blue collar worker & $91(1.3)$ & $42(46.2)$ & $49(53.8)$ & $\begin{array}{l}1.252[.808, \\
1.940]\end{array}$ & $<.001$ & $1.057[.624,1.789]$ & .837 \\
\hline Profession/white collar worker & $\begin{array}{l}2980 \\
(41.4) \\
\end{array}$ & $1133(38)$ & $1847(62)$ & $\begin{array}{l}.896[.759, \\
1.058] \\
\end{array}$ & & $1.051[.845,1.306]$ & .657 \\
\hline Self-employed & $575(8)$ & $254(44.2)$ & $321(55.8)$ & $\begin{array}{l}1.156[.925, \\
1.443]\end{array}$ & & $.776[.586,1.026]$ & .075 \\
\hline
\end{tabular}




\begin{tabular}{|c|c|c|c|c|c|c|c|}
\hline Student & $\begin{array}{l}2831 \\
(39.4)\end{array}$ & $976(34.5)$ & $\begin{array}{l}1855 \\
(65.5)\end{array}$ & $\begin{array}{l}.768[.650, \\
.909]\end{array}$ & & $1.352[1.046,1.749]$ & .021 \\
\hline \multicolumn{8}{|c|}{ Housewife/retired/unemployed/other } \\
\hline \multicolumn{8}{|l|}{ Monthly Income (PHP) } \\
\hline$\leq 10,000$ & $\begin{array}{l}2583 \\
(35.9)\end{array}$ & $\begin{array}{l}1004 \\
(38.9)\end{array}$ & $\begin{array}{l}1579 \\
(61.1)\end{array}$ & $\begin{array}{l}1.649 \\
{[1.417} \\
1.919]\end{array}$ & $<.001$ & $.596[.477, .745]$ & $<.001$ \\
\hline $10,000-20,000$ & $\begin{array}{l}954 \\
(13.3)\end{array}$ & $468(49.1)$ & $486(50.9)$ & $\begin{array}{l}2.497 \\
{[2.083,} \\
2.994]\end{array}$ & & $.587[.465, .741]$ & $<.001$ \\
\hline $20,000-100,000$ & $\begin{array}{l}2517 \\
(35)\end{array}$ & $907(36)$ & $1610(64)$ & $\begin{array}{l}1.461 \\
{[1.254,} \\
1.702]\end{array}$ & & $.822[.679, .995]$ & .044 \\
\hline$\geq 100,000$ & $\begin{array}{l}1139 \\
(15.8)\end{array}$ & $317(27.8)$ & $822(72.2)$ & Reference & & Reference & \\
\hline \multicolumn{8}{|l|}{ Location } \\
\hline Urban & $\begin{array}{l}5676 \\
(78.9)\end{array}$ & $1985(35)$ & $3691(65)$ & & & Reference & \\
\hline Rural & $\begin{array}{l}1517 \\
(21.1)\end{array}$ & $711(46.9)$ & $806(53.1)$ & $\begin{array}{l}1.640 \\
{[1.463,} \\
1.840]\end{array}$ & $<.001$ & $.728[.634, .836]$ & $<.001$ \\
\hline \multicolumn{8}{|c|}{ Experience with COVID-19 } \\
\hline \multicolumn{8}{|c|}{ Ever tested positive for COVID-19 } \\
\hline Yes & $\begin{array}{l}211 \\
(2.9) \\
\end{array}$ & $68(32.2)$ & $143(67.8)$ & & & & \\
\hline No & $\begin{array}{l}6982 \\
(97.1) \\
\end{array}$ & $\begin{array}{l}2628 \\
(37.6)\end{array}$ & $\begin{array}{l}4354 \\
(62.4) \\
\end{array}$ & $\begin{array}{l}.788[.588, \\
1.056]\end{array}$ & .110 & & \\
\hline \multicolumn{8}{|c|}{$\begin{array}{l}\text { Know anyone who has tested } \\
\text { positive for COVID-19 }\end{array}$} \\
\hline Yes & $\begin{array}{l}5234 \\
(72.8)\end{array}$ & $1780(34)$ & $3454(66)$ & & & $1.535[1.348,1.748]$ & $<.001$ \\
\hline No & $\begin{array}{l}1959 \\
(27.2) \\
\end{array}$ & $916(46.8)$ & $\begin{array}{l}1043 \\
(53.2) \\
\end{array}$ & $\begin{array}{l}.587[.528, \\
.652]\end{array}$ & $<.001$ & Reference & \\
\hline \multicolumn{8}{|l|}{ Health Characteristics } \\
\hline \multicolumn{8}{|c|}{ Have an existing chronic condition } \\
\hline Yes & $\begin{array}{l}1178 \\
(16.4) \\
\end{array}$ & $396(33.6)$ & $782(66.4)$ & & & $1.149[.964,1.369]$ & .121 \\
\hline No & $\begin{array}{l}6015 \\
(83.6) \\
\end{array}$ & $\begin{array}{l}2300 \\
(38.2)\end{array}$ & $\begin{array}{l}3715 \\
(61.8) \\
\end{array}$ & $\begin{array}{l}.818[.717, \\
.933]\end{array}$ & .003 & Reference & \\
\hline \multicolumn{8}{|l|}{ Perceived overall health } \\
\hline Very good & $\begin{array}{l}1997 \\
(27.8)\end{array}$ & $802(40.2)$ & $\begin{array}{l}1195 \\
(59.8)\end{array}$ & Reference & & Reference & \\
\hline Good & $\begin{array}{l}3934 \\
(54.7) \\
\end{array}$ & $1376(35)$ & $2558(65)$ & $\begin{array}{l}.802[.717, \\
.896]\end{array}$ & $<.001$ & $1.173[1.024,1.343]$ & .021 \\
\hline Fair/Poor/Very poor & $\begin{array}{l}1262 \\
(17.5)\end{array}$ & $518(41)$ & $744(59)$ & $\begin{array}{l}1.037[.899 \\
1.197]\end{array}$ & & $.755[.632, .903]$ & .002 \\
\hline
\end{tabular}




\begin{tabular}{|c|c|c|c|c|c|c|c|}
\hline Health belief & & & & & & & \\
\hline \multicolumn{8}{|l|}{ Perceived susceptibility } \\
\hline \multicolumn{8}{|c|}{$\begin{array}{l}\text { Chance of getting COVID-19 in the } \\
\text { next few months is high }\end{array}$} \\
\hline Strongly agree/agree & $\begin{array}{l}2264 \\
(31.5)\end{array}$ & $\begin{array}{l}1595 \\
(70.5)\end{array}$ & $669(29.5)$ & $\begin{array}{l}1.665 \\
{[1.497} \\
1.853]\end{array}$ & $<.001$ & Reference & \\
\hline Disagree/strongly disagree & $\begin{array}{l}4929 \\
(68.5) \\
\end{array}$ & $\begin{array}{l}2027 \\
(41.1)\end{array}$ & $\begin{array}{l}2902 \\
(58.9)\end{array}$ & & & $.728[.639, .830]$ & $<.001$ \\
\hline \multicolumn{8}{|l|}{$\begin{array}{l}\text { Worry about the likelihood of } \\
\text { getting COVID-19 }\end{array}$} \\
\hline Strongly agree/agree & $\begin{array}{l}6047 \\
(84.1)\end{array}$ & $\begin{array}{l}2105 \\
(34.8)\end{array}$ & $\begin{array}{l}3942 \\
(65.2)\end{array}$ & $\begin{array}{l}1.994 \\
{[1.756} \\
2.265]\end{array}$ & $<.001$ & Reference & \\
\hline Disagree/strongly disagree & $\begin{array}{l}1146 \\
(15.9)\end{array}$ & $591(51.6)$ & $555(48.4)$ & & & $.696[.584, .830]$ & $<.001$ \\
\hline \multicolumn{8}{|l|}{ Perceived severity } \\
\hline \multicolumn{8}{|l|}{$\begin{array}{l}\text { COVID-19 is serious with life- } \\
\text { threatening complications }\end{array}$} \\
\hline Strongly agree/agree & $\begin{array}{l}6928 \\
(96.3)\end{array}$ & $\begin{array}{l}2523 \\
(36.4)\end{array}$ & $\begin{array}{l}4405 \\
(63.6)\end{array}$ & $\begin{array}{l}3.283 \\
{[2.538} \\
4.248]\end{array}$ & $<.001$ & Reference & \\
\hline Disagree/strongly disagree & $\begin{array}{l}265 \\
(.04) \\
\end{array}$ & $173(65.3)$ & $95(34.7)$ & & & $.580[.410, .820]$ & .002 \\
\hline \multicolumn{8}{|c|}{$\begin{array}{l}\text { I will be very sick if I get COVID- } \\
19\end{array}$} \\
\hline Strongly agree/agree & $\begin{array}{l}5394 \\
(75)\end{array}$ & $\begin{array}{l}1911 \\
(35.4)\end{array}$ & $\begin{array}{l}3483 \\
(64.6)\end{array}$ & $\begin{array}{l}1.411 \\
{[1.266} \\
1.573]\end{array}$ & $<.001$ & Reference & \\
\hline Disagree/strongly disagree & $\begin{array}{l}1799 \\
(25)\end{array}$ & $785(43.6)$ & $\begin{array}{l}1014 \\
(56.4)\end{array}$ & & & $.824[.711, .954]$ & .010 \\
\hline \multicolumn{8}{|c|}{ I am afraid of getting COVID-19 } \\
\hline Strongly agree/agree & $\begin{array}{l}6700 \\
(93.1)\end{array}$ & $\begin{array}{l}2439 \\
(36.4)\end{array}$ & $\begin{array}{l}4261 \\
(63.6)\end{array}$ & $\begin{array}{l}1.902 \\
{[1.583} \\
2.286]\end{array}$ & $<.001$ & Reference & \\
\hline Disagree/strongly disagree & $\begin{array}{l}493 \\
(.07) \\
\end{array}$ & $257(52.1)$ & $236(47.9)$ & & & $.676[.513, .889]$ & .005 \\
\hline \multicolumn{8}{|l|}{ Perceived benefits } \\
\hline \multicolumn{8}{|l|}{$\begin{array}{l}\text { Vaccination will decrease my } \\
\text { chances of getting COVID-19 }\end{array}$} \\
\hline Strongly agree/agree & $\begin{array}{l}6339 \\
(88.1)\end{array}$ & $\begin{array}{l}2006 \\
(31.6)\end{array}$ & $\begin{array}{l}4333 \\
(68.4)\end{array}$ & $\begin{array}{l}9.088 \\
{[7.604,} \\
10.862]\end{array}$ & $<.001$ & Reference & \\
\hline Disagree/strongly disagree & $\begin{array}{l}854 \\
(11.9) \\
\end{array}$ & $690(80.8)$ & $164(19.2)$ & & & $.291[.229, .370]$ & $<.001$ \\
\hline \multicolumn{8}{|c|}{$\begin{array}{l}\text { Vaccination will decrease my } \\
\text { worries about catching COVID-19 }\end{array}$} \\
\hline Strongly agree/agree & 6078 & 1833 & 4245 & 7.931 & $<.001$ & Reference & \\
\hline
\end{tabular}




\begin{tabular}{|c|c|c|c|c|c|c|c|}
\hline & $(84.5)$ & $(30.2)$ & $(69.8)$ & $\begin{array}{l}{[6.822,} \\
9.220]\end{array}$ & & & \\
\hline Disagree/strongly disagree & $\begin{array}{l}1115 \\
(15.5)\end{array}$ & $863(77.4)$ & $252(22.6)$ & & & $.265[.218, .323]$ & $<.001$ \\
\hline \multicolumn{8}{|l|}{ Perceived barriers } \\
\hline \multicolumn{8}{|c|}{$\begin{array}{l}\text { Worry about the possible side- } \\
\text { effects of the COVID-19 vaccine }\end{array}$} \\
\hline Strongly agree/agree & $\begin{array}{l}6447 \\
(89.6) \\
\end{array}$ & $\begin{array}{l}2647 \\
(41.1)\end{array}$ & $\begin{array}{l}3800 \\
(58.9)\end{array}$ & $\begin{array}{l}.101[.075 \\
.135]\end{array}$ & $<.001$ & Reference & \\
\hline Disagree/strongly disagree & $\begin{array}{l}746 \\
(10.4)\end{array}$ & $49(6.6)$ & $697(93.4)$ & & & $3.053[2.107,4.424]$ & $<.001$ \\
\hline \multicolumn{8}{|c|}{$\begin{array}{l}\text { I worry about the effectiveness of } \\
\text { the COVID- } 19 \text { vaccine }\end{array}$} \\
\hline Strongly agree/agree & $\begin{array}{l}6263 \\
(87.1)\end{array}$ & $\begin{array}{l}2581 \\
(41.2)\end{array}$ & $\begin{array}{l}3682 \\
(58.8)\end{array}$ & $\begin{array}{l}.201[.165 \\
.246]\end{array}$ & $<.001$ & Reference & \\
\hline Disagree/strongly disagree & $\begin{array}{l}930 \\
(12.9)\end{array}$ & $115(12.4)$ & $815(87.6)$ & & & $1.358[1.022,1.805]$ & .035 \\
\hline \multicolumn{8}{|l|}{$\begin{array}{l}\text { I worry about the safety of the } \\
\text { COVID-19 vaccine }\end{array}$} \\
\hline Strongly agree/agree & $\begin{array}{l}6389 \\
(88.8)\end{array}$ & $\begin{array}{l}2626 \\
(41.1)\end{array}$ & $\begin{array}{l}3763 \\
(58.9)\end{array}$ & $\begin{array}{l}.137[.106, \\
.176]\end{array}$ & $<.001$ & Reference & \\
\hline Disagree/strongly disagree & $\begin{array}{l}804 \\
(11.2) \\
\end{array}$ & $70(8.7)$ & $734(91.3)$ & & & $1.593[1.115,2.277]$ & .011 \\
\hline \multicolumn{8}{|c|}{$\begin{array}{l}\text { I worry about the high cost of the } \\
\text { COVID-19 vaccine }\end{array}$} \\
\hline Strongly agree/agree & $\begin{array}{l}5608 \\
(78) \\
\end{array}$ & $2301(41)$ & $3307(59)$ & $\begin{array}{l}.477[.421 \\
.541]\end{array}$ & $<.001$ & Reference & \\
\hline Disagree/strongly disagree & $\begin{array}{l}1585 \\
(22)\end{array}$ & $395(24.9)$ & $\begin{array}{l}1190 \\
(75.1)\end{array}$ & & & $1.128[.958,1.327]$ & .147 \\
\hline \multicolumn{8}{|l|}{$\begin{array}{l}\text { I worry about fake COVID-19 } \\
\text { vaccines }\end{array}$} \\
\hline Strongly agree/agree & $\begin{array}{l}7006 \\
(97.4)\end{array}$ & $\begin{array}{l}2646 \\
(37.8)\end{array}$ & $\begin{array}{l}4360 \\
(62.2)\end{array}$ & $\begin{array}{l}.601[.433 \\
.834]\end{array}$ & .002 & Reference & \\
\hline Disagree/strongly disagree & $\begin{array}{l}187 \\
(.03) \\
\end{array}$ & $50(26.7)$ & $197(73.3)$ & & & $.599[.399, .900]$ & .014 \\
\hline \multicolumn{8}{|c|}{$\begin{array}{l}\text { I worry that the COVID-19 vaccines } \\
\text { will make me sick }\end{array}$} \\
\hline Strongly agree/agree & $\begin{array}{l}4918 \\
(68.4) \\
\end{array}$ & $\begin{array}{l}2404 \\
(48.9) \\
\end{array}$ & $\begin{array}{l}2514 \\
(51.1) \\
\end{array}$ & $\begin{array}{l}.154[.135 \\
.176] \\
\end{array}$ & $<.001$ & Reference & \\
\hline Disagree/strongly disagree & $\begin{array}{l}2275 \\
(31.6)\end{array}$ & $292(12.8)$ & $\begin{array}{l}1983 \\
(87.2)\end{array}$ & & & $2.913[2.467,3.440]$ & $<.001$ \\
\hline \multicolumn{8}{|c|}{$\begin{array}{l}\text { I worry the COVID- } 19 \text { vaccines will } \\
\text { not be effective against new virus } \\
\text { variants }\end{array}$} \\
\hline Strongly agree/agree & $\begin{array}{l}5757 \\
(80) \\
\end{array}$ & $\begin{array}{l}2506 \\
(43.5) \\
\end{array}$ & $\begin{array}{l}3251 \\
(56.5) \\
\end{array}$ & $\begin{array}{l}.198[.168, \\
.232]\end{array}$ & $<.001$ & Reference & \\
\hline Disagree/strongly disagree & $\begin{array}{l}1436 \\
(20)\end{array}$ & $190(13.2)$ & $\begin{array}{l}1246 \\
(86.8)\end{array}$ & & & $1.831[1.502,2.232]$ & $<.001$ \\
\hline
\end{tabular}




\begin{tabular}{|c|c|c|c|c|c|c|c|}
\hline Cues to action & & & & & & & \\
\hline \multicolumn{8}{|c|}{$\begin{array}{l}\text { I will only receive the COVID-19 } \\
\text { vaccines after many others receive it }\end{array}$} \\
\hline Strongly agree/agree & $\begin{array}{l}5237 \\
(72.8)\end{array}$ & $\begin{array}{l}2278 \\
(43.5)\end{array}$ & $\begin{array}{l}2959 \\
(56.5)\end{array}$ & $\begin{array}{l}.353[.313, \\
.398]\end{array}$ & $<.001$ & Reference & \\
\hline Disagree/strongly disagree & $\begin{array}{l}1956 \\
(27.2)\end{array}$ & $418(21.4)$ & $\begin{array}{l}1538 \\
(78.6)\end{array}$ & & & $1.894[1.597,2.247]$ & $<.001$ \\
\hline \multicolumn{8}{|c|}{$\begin{array}{l}\text { I will only receive the COVID-19 } \\
\text { vaccines after politicians receive it }\end{array}$} \\
\hline Strongly agree/agree & $\begin{array}{l}4908 \\
(68.2)\end{array}$ & $\begin{array}{l}2124 \\
(43.3)\end{array}$ & $\begin{array}{l}2784 \\
(56.7)\end{array}$ & $\begin{array}{l}.438[.392, \\
.489]\end{array}$ & $<.001$ & Reference & \\
\hline Disagree/strongly disagree & $\begin{array}{l}2285 \\
(31.8)\end{array}$ & $572(25)$ & $1713(75)$ & & & $1.411[1.214,1.640]$ & $<.001$ \\
\hline
\end{tabular}

4

5

6 
Table 3 (on next page)

Willingness to Pay for a COVID-19 Vaccine in the Philippines 
1

2

\begin{tabular}{|c|c|}
\hline $\begin{array}{c}\text { Maximum Amount Willing to Pay } \\
\text { (PHP: Philippine Peso) }\end{array}$ & \% of Respondents \\
\hline PHP 500 & $18.8 \%$ \\
\hline PHP 1,000 & $21 \%$ \\
\hline PHP 1,500 & $12 \%$ \\
\hline PHP 2,000 & $16 \%$ \\
\hline PHP 2,500 & $6.8 \%$ \\
\hline PHP 3,000 & $8.8 \%$ \\
\hline PHP 3,500 & $1.9 \%$ \\
\hline PHP 4,000 & $14.7 \%$ \\
\hline
\end{tabular}

3

4

5

6

7

8

Table 3: Willingness to Pay for a COVID-19 Vaccine

7

8 


\section{Table 4 (on next page)}

Multinomial Logistic Regression of Factors Associated with Marginal Willingness-to-Pay (WTP) for a COVID-19 vaccine $(\mathrm{N}=7,193)$ 
1 Table 4: Multinomial Logistic Regression of Factors Associated with Marginal Willingness2 to-Pay (WTP) for a COVID-19 vaccine $(\mathrm{N}=7,193)$

3

\begin{tabular}{|c|c|c|c|c|c|c|c|c|}
\hline & \multirow{2}{*}{\multicolumn{3}{|c|}{$\begin{array}{c}\text { Univariable analysis } \\
\text { Marginal WTP }(\mathbf{P}=\text { PHP })\end{array}$}} & & \multicolumn{4}{|c|}{ Multinomial logistic regression } \\
\hline & & & & & \multirow[b]{2}{*}{$\begin{array}{c}\text { P1500/200 } \\
0 \\
/ 2500 \\
\text { OR [95\% } \\
\text { CI] }\end{array}$} & \multirow[b]{2}{*}{$\begin{array}{c}p \text { - } \\
\text { valu } \\
\text { e }\end{array}$} & \multirow[b]{2}{*}{$\begin{array}{c}\mathbf{P 3 0 0 0} / 35 \\
00 \\
/ 4000 \\
\text { OR } \\
{[95 \%} \\
\text { CI }]\end{array}$} & \multirow[b]{2}{*}{$\begin{array}{c}p- \\
\text { valu } \\
\text { e }\end{array}$} \\
\hline & $\begin{array}{c}\text { P500/100 } \\
0 \\
(\mathrm{US} \\
\$ 10.18 / \\
20.36) \\
\mathbf{n}=\mathbf{2 8 6 2} \\
(\%)\end{array}$ & $\begin{array}{c}\mathbf{P 1 5 0 0} / \mathbf{2 0 0 0} \\
/ 2500 \\
(\mathbf{U S} \\
\mathbf{\$ 3 0 . 5 5} / 40.7 \\
\mathbf{3} \\
/ \mathbf{5 0 . 9 1 )} \\
\mathbf{n}=\mathbf{2 5 0 5} \\
(\%)\end{array}$ & $\begin{array}{c}\text { P3000/350 } \\
0 \\
/ 4000 \\
(\text { US \$ } \\
61.09 / 71.2 \\
8 \\
/ 81.46) \\
\mathbf{n}=1826 \\
(\%)\end{array}$ & $\begin{array}{c}p- \\
\text { valu } \\
\text { e }\end{array}$ & & & & \\
\hline \multicolumn{9}{|l|}{ Demographics } \\
\hline \multicolumn{9}{|l|}{ Age group (years) } \\
\hline $18-30$ & $\begin{array}{c}1349 \\
(35.8)\end{array}$ & $1480(39.3)$ & $941(25)$ & $<.001$ & $\begin{array}{l}1.895 \\
{[1.401,} \\
2.563]\end{array}$ & $<.001$ & $\begin{array}{l}2.344 \\
{[1.616,} \\
3.400]\end{array}$ & $<.001$ \\
\hline $31-40$ & $352(43.2)$ & $233(28.6)$ & $230(28.2)$ & & $\begin{array}{l}1.960 \\
{[1.401,} \\
2.611]\end{array}$ & $<.001$ & $\begin{array}{l}2.895 \\
{[2.045,} \\
4.100]\end{array}$ & $<.001$ \\
\hline $41-50$ & $363(42.2)$ & $266(30.9)$ & $232(26.9)$ & & $\begin{array}{l}1.640 \\
{[1.256,} \\
2.143]\end{array}$ & $<.001$ & $\begin{array}{l}1.812 \\
{[1.309} \\
2.507]\end{array}$ & $<.001$ \\
\hline $51-60$ & $418(46.4)$ & $269(29.9)$ & $213(23.7)$ & & $\begin{array}{l}1.261[.982, \\
1.621]\end{array}$ & .070 & $\begin{array}{l}1.229 \\
{[.902,} \\
1.675]\end{array}$ & .192 \\
\hline $61-89$ & $380(44.9)$ & $257(30.3)$ & $210(24.8)$ & & Reference & & Reference & \\
\hline \multicolumn{9}{|l|}{ Gender } \\
\hline Female & $\begin{array}{c}1912 \\
(39.9)\end{array}$ & $1682(35.1)$ & $1195(25)$ & .391 & & & & \\
\hline Male & $950(39.5)$ & $823(34.2)$ & $631(26.2)$ & & & & & \\
\hline \multicolumn{9}{|l|}{ Marital Status } \\
\hline Single & $\begin{array}{c}1727 \\
(36.6)\end{array}$ & $1768(37.4)$ & $1229(26)$ & $<.001$ & $\begin{array}{l}1.200 \\
{[1.003,} \\
1.436]\end{array}$ & .046 & $\begin{array}{l}1.328 \\
{[1.069,} \\
1.649]\end{array}$ & .010 \\
\hline Married & $1135(46)$ & $737(29.9)$ & $597(24.2)$ & & Reference & & Reference & \\
\hline \multicolumn{9}{|l|}{ Highest Education Level } \\
\hline Elementary school or below & 1 & & & \multicolumn{5}{|c|}{$n$ too small to calculate } \\
\hline Junior high school & $19(41.3)$ & $14(30.4)$ & $13(28.3)$ & & $\begin{array}{l}.838[.396, \\
1.771]\end{array}$ & .643 & $\begin{array}{l}1.958 \\
{[.899,} \\
4.264]\end{array}$ & .091 \\
\hline Senior high school & $328(29.8)$ & $474(43)$ & $300(27.2)$ & $<.001$ & $\begin{array}{l}1.153[.956, \\
1.390]\end{array}$ & .136 & $\begin{array}{l}1.203 \\
{[.958,} \\
1.510]\end{array}$ & .111 \\
\hline College/university of above & 2514 & $2017(33.4)$ & $1513(25)$ & & Reference & & Reference & \\
\hline
\end{tabular}




\begin{tabular}{|c|c|c|c|c|c|c|c|c|}
\hline & $(41.6)$ & & & & & & & \\
\hline \multicolumn{9}{|l|}{ Occupation } \\
\hline Blue collar worker & $69(75.8)$ & $13(14.3)$ & $9(9.9)$ & $<.001$ & $\begin{array}{l}.238[.124, \\
.456]\end{array}$ & $<.001$ & $\begin{array}{l}.304[.135 \\
.681]\end{array}$ & .004 \\
\hline $\begin{array}{l}\text { Professional/white collar } \\
\text { worker }\end{array}$ & $\begin{array}{c}1382 \\
(46.4)\end{array}$ & 845 (28.4) & $753(25.3)$ & & $\begin{array}{l}.681[.539, \\
.860]\end{array}$ & .001 & $\begin{array}{l}.866[.644, \\
1.163]\end{array}$ & .339 \\
\hline Self-employed & $226(39.3)$ & $204(35.5)$ & $145(25.2)$ & & $\begin{array}{l}1.052[.795 \\
1.393]\end{array}$ & .722 & $\begin{array}{l}1.127 \\
{[.785,} \\
1.616] \\
\end{array}$ & .517 \\
\hline Student & $585(30.3)$ & $1213(42.8)$ & $760(26.8)$ & & $\begin{array}{l}1.614 \\
{[1.206,} \\
2.159]\end{array}$ & .001 & $\begin{array}{l}1.725 \\
{[1.190} \\
2.501]\end{array}$ & .004 \\
\hline $\begin{array}{l}\text { Housewife/retired/unemployed/ot } \\
\text { her }\end{array}$ & $327(45.7)$ & $230(32.1)$ & $159(22.2)$ & & Reference & & Reference & \\
\hline \multicolumn{9}{|l|}{ Monthly Income (PHP) } \\
\hline$\leq 10,000$ & $986(38.2)$ & $995(38.5)$ & $602(23.3)$ & & $\begin{array}{l}.378[.298, \\
.480]\end{array}$ & $<.001$ & $\begin{array}{l}.252[.191 \\
.333]\end{array}$ & $<.001$ \\
\hline $10,000-20,000$ & $554(58.1)$ & $272(28.5)$ & $128(13.4)$ & $<.001$ & $\begin{array}{l}.389[.305, \\
.497]\end{array}$ & $<.001$ & $\begin{array}{l}.211[.156 \\
.286]\end{array}$ & $<.001$ \\
\hline $20,000-100,000$ & $\begin{array}{r}1047 \\
(41.6) \\
\end{array}$ & 849 (33.7) & $621(24.7)$ & & $\begin{array}{l}.614[.503, \\
.749]\end{array}$ & $<.001$ & $\begin{array}{l}.452[.362 \\
.563]\end{array}$ & $<.001$ \\
\hline$\geq 100,000$ & $275(24.1)$ & $389(34.2)$ & $475(41.7)$ & & Reference & & Reference & \\
\hline \multicolumn{9}{|l|}{ Location } \\
\hline Urban & $\begin{array}{c}2053 \\
(36.2) \\
\end{array}$ & $2068(36.4)$ & $1555(27.4)$ & & Reference & & Reference & \\
\hline Rural & $809(53.3)$ & $437(28.8)$ & $271(17.9)$ & $<.001$ & $\begin{array}{l}.584[.505, \\
.674]\end{array}$ & $<.001$ & $\begin{array}{l}.552[.460, \\
.662]\end{array}$ & $<.001$ \\
\hline \multicolumn{9}{|l|}{ Experience with COVID-19 } \\
\hline \multicolumn{9}{|l|}{$\begin{array}{l}\text { Ever tested positive for COVID- } \\
19\end{array}$} \\
\hline Yes & $80(37.9)$ & $66(31.3)$ & $65(30.8)$ & .176 & & & & \\
\hline No & $\begin{array}{c}2782 \\
(39.8) \\
\end{array}$ & $2439(34.9)$ & $1761(25.2)$ & & & & & \\
\hline \multicolumn{9}{|l|}{$\begin{array}{l}\text { Know anyone who has tested } \\
\text { positive for COVID-19 }\end{array}$} \\
\hline Yes & $\begin{array}{c}1932 \\
(36.9)\end{array}$ & $1868(35.7)$ & $1434(27.4)$ & $<.001$ & $\begin{array}{l}1.336 \\
{[1.169,} \\
1.527]\end{array}$ & $<.001$ & $\begin{array}{l}1.419 \\
{[1.201,} \\
1.678]\end{array}$ & $<.001$ \\
\hline No & $930(47.5)$ & $637(32.5)$ & $392(20)$ & & Reference & & Reference & \\
\hline \multicolumn{9}{|l|}{ Health Characteristics } \\
\hline \multicolumn{9}{|l|}{$\begin{array}{l}\text { Have an existing chronic } \\
\text { condition }\end{array}$} \\
\hline Yes & $438(37.2)$ & 387 (32.9) & $353(30)$ & .001 & $\begin{array}{l}1.176[.981, \\
1.410]\end{array}$ & .080 & $\begin{array}{l}1.430 \\
{[1.152,} \\
1.775]\end{array}$ & .001 \\
\hline No & 2424 & $2118(35.2)$ & $1473(24.5)$ & & Reference & & Reference & \\
\hline
\end{tabular}




\begin{tabular}{|c|c|c|c|c|c|c|c|c|}
\hline & $(40.3)$ & & & & & & & \\
\hline \multicolumn{9}{|l|}{ Perceived overall health } \\
\hline Very good & $852(42.7)$ & $641(32.1)$ & $504(25.2)$ & & Reference & & Reference & \\
\hline Good & $\begin{array}{c}1559 \\
(39.6)\end{array}$ & $1385(35.2)$ & $990(25.2)$ & & $\begin{array}{l}1.160 \\
{[1.010,} \\
1.332]\end{array}$ & .035 & $\begin{array}{l}1.052 \\
{[.891,} \\
1.243]\end{array}$ & .549 \\
\hline Fair/Poor/Very poor & $451(35.7)$ & $479(38)$ & $332(26.3)$ & .020 & $\begin{array}{l}1.287 \\
{[1.071} \\
1.547]\end{array}$ & .007 & $\begin{array}{l}1.090 \\
{[.872,} \\
1.364]\end{array}$ & .450 \\
\hline \multicolumn{9}{|l|}{ Health belief } \\
\hline \multicolumn{9}{|l|}{ Perceived susceptibility } \\
\hline \multicolumn{9}{|l|}{$\begin{array}{l}\text { Chance of getting COVID-19 in } \\
\text { the next few months is high }\end{array}$} \\
\hline Strongly agree/agree & $838(37)$ & $790(34.9)$ & $636(28.1)$ & $<.001$ & Reference & & Reference & \\
\hline Disagree/strongly disagree & $\begin{array}{c}2024 \\
(41.1) \\
\end{array}$ & $1715(34.8)$ & $1190(24.1)$ & & $\begin{array}{l}.989[.868 \\
1.128] \\
\end{array}$ & .872 & $\begin{array}{l}.916[.783 \\
1.071] \\
\end{array}$ & .270 \\
\hline \multicolumn{9}{|l|}{$\begin{array}{l}\text { Worry about the likelihood of } \\
\text { getting COVID-19 }\end{array}$} \\
\hline Strongly agree/agree & $\begin{array}{c}2272 \\
(37.6)\end{array}$ & $2175(36)$ & $1600(26.5)$ & $<.001$ & Reference & & Reference & \\
\hline Disagree/strongly disagree & $590(51.5)$ & $330(28.8)$ & $226(19.7)$ & & $\begin{array}{l}.763[.638, \\
.912] \\
\end{array}$ & .003 & $\begin{array}{l}.690[.551, \\
.866] \\
\end{array}$ & .001 \\
\hline \multicolumn{9}{|l|}{ Perceived severity } \\
\hline \multicolumn{9}{|l|}{$\begin{array}{l}\text { COVID-19 is serious with life- } \\
\text { threatening complications }\end{array}$} \\
\hline Strongly agree/agree & $2699(39)$ & $2441(35.2)$ & $1788(25.8)$ & $<.001$ & Reference & & Reference & \\
\hline Disagree/strongly disagree & $163(61.5)$ & $64(24.2)$ & $38(14.3)$ & & $\begin{array}{l}.681[.484, \\
.960]\end{array}$ & .028 & $\begin{array}{l}.562[.654 \\
.891] \\
\end{array}$ & .014 \\
\hline \multicolumn{9}{|l|}{$\begin{array}{l}\text { I will be very sick if I get } \\
\text { COVID-19 }\end{array}$} \\
\hline Strongly agree/agree & $2048(38)$ & $1931(35.8)$ & $1415(26.2)$ & $<.001$ & Reference & & Reference & \\
\hline Disagree/strongly disagree & $814(45.2)$ & $574(31.9)$ & $411(22.8)$ & & $\begin{array}{l}.883[.762 \\
1.023]\end{array}$ & .097 & $\begin{array}{l}.784[.654, \\
.940]\end{array}$ & .009 \\
\hline \multicolumn{9}{|l|}{ I am afraid of getting COVID-19 } \\
\hline Strongly agree/agree & $\begin{array}{c}2619 \\
(39.1) \\
\end{array}$ & $2354(35.1)$ & $1727(25.8)$ & $<.001$ & Reference & & Reference & \\
\hline Disagree/strongly disagree & $243(49.3)$ & $151(30.6)$ & $99(20.1)$ & & $\begin{array}{l}.989[.759 \\
1.290]\end{array}$ & .938 & $\begin{array}{l}.794[.562 \\
1.122]\end{array}$ & .192 \\
\hline \multicolumn{9}{|l|}{ Perceived benefits } \\
\hline \multicolumn{9}{|l|}{$\begin{array}{l}\text { Vaccination will decrease my } \\
\text { chances of getting COVID-19 }\end{array}$} \\
\hline Strongly agree/agree & $\begin{array}{l}2341 \\
(36.9)\end{array}$ & $2289(36.1)$ & $1709(27)$ & $<.001$ & Reference & & Reference & \\
\hline
\end{tabular}




\begin{tabular}{|c|c|c|c|c|c|c|c|c|}
\hline Disagree/strongly disagree & $521(61)$ & $216(25.3)$ & $117(13.7)$ & & $\begin{array}{l}.666[.526, \\
.842]\end{array}$ & .001 & $\begin{array}{l}.532[.391 \\
.724]\end{array}$ & $<.001$ \\
\hline \multicolumn{9}{|l|}{$\begin{array}{l}\text { Vaccination will decrease my } \\
\text { worries about catching COVID- } \\
19\end{array}$} \\
\hline Strongly agree/agree & $2248(37)$ & $2180(35.9)$ & $1650(27.1)$ & $<.001$ & Reference & & Reference & \\
\hline Disagree/strongly disagree & $614(55.1)$ & $325(29.1)$ & $176(15.8)$ & & & & $\begin{array}{l}.688[.529 \\
.895]\end{array}$ & .005 \\
\hline \multicolumn{9}{|l|}{ Perceived barriers } \\
\hline \multicolumn{9}{|c|}{$\begin{array}{l}\text { Worry about the possible side- } \\
\text { effects of the COVID-19 vaccine }\end{array}$} \\
\hline Strongly agree/agree & $\begin{array}{l}2701 \\
(41.9)\end{array}$ & $2212(34.3)$ & $1534(23.8)$ & $<.001$ & Reference & & Reference & \\
\hline Disagree/strongly disagree & $161(21.6)$ & $293(39.3)$ & $292(39.1)$ & & $\begin{array}{l}1.421 \\
{[1.103} \\
1.831]\end{array}$ & .007 & $\begin{array}{l}1.262 \\
{[.945} \\
1.684]\end{array}$ & .114 \\
\hline \multicolumn{9}{|c|}{$\begin{array}{l}\text { I worry about the effectiveness of } \\
\text { the COVID- } 19 \text { vaccine }\end{array}$} \\
\hline Strongly agree/agree & $\begin{array}{c}2590 \\
(41.4)\end{array}$ & $2184(34.9)$ & $1489(23.8)$ & $<.001$ & Reference & & Reference & \\
\hline Disagree/strongly disagree & $272(29.2)$ & $321(34.5)$ & $337(36.2)$ & & $\begin{array}{l}.917[.712 \\
1.182]\end{array}$ & .505 & $\begin{array}{l}.756[.564 \\
1.015]\end{array}$ & .063 \\
\hline \multicolumn{9}{|l|}{$\begin{array}{l}\text { I worry about the safety of the } \\
\text { COVID- } 19 \text { vaccine }\end{array}$} \\
\hline Strongly agree/agree & $\begin{array}{l}2637 \\
(41.3)\end{array}$ & $2240(35.1)$ & $1512(23.7)$ & $<.001$ & Reference & & Reference & \\
\hline Disagree/strongly disagree & $225(28)$ & $265(33)$ & $314(39.1)$ & & $\begin{array}{l}.768[.578 \\
1.022]\end{array}$ & .070 & $\begin{array}{l}.895[.645 \\
1.243]\end{array}$ & .508 \\
\hline \multicolumn{9}{|c|}{$\begin{array}{l}\text { I worry about the high cost of the } \\
\text { COVID-19 vaccine }\end{array}$} \\
\hline Strongly agree/agree & $\begin{array}{c}2616 \\
(46.6)\end{array}$ & $1991(35.5)$ & $1001(17.8)$ & $<.001$ & Reference & & Reference & \\
\hline Disagree/strongly disagree & $246(15.5)$ & $514(32.4)$ & $825(52.1)$ & & $\begin{array}{l}2.534 \\
{[2.107} \\
3.048]\end{array}$ & $<.001$ & $\begin{array}{l}7.321 \\
{[6.065} \\
8.836] \\
\end{array}$ & $<.001$ \\
\hline \multicolumn{9}{|l|}{$\begin{array}{l}\text { I worry about fake COVID-19 } \\
\text { vaccines }\end{array}$} \\
\hline Strongly agree/agree & $\begin{array}{c}2809 \\
(40.1) \\
\end{array}$ & $2452(35)$ & $1745(24.9)$ & $<.001$ & Reference & & Reference & \\
\hline Disagree/strongly disagree & $53(28.3)$ & $53(28.3)$ & $81(43.3)$ & & $\begin{array}{l}.723[.471 \\
1.108]\end{array}$ & .136 & $\begin{array}{l}1.093 \\
{[.707} \\
1.690]\end{array}$ & .688 \\
\hline $\begin{array}{l}\text { I worry that the COVID-19 } \\
\text { vaccines will make me sick }\end{array}$ & & & & & & & & \\
\hline
\end{tabular}




\begin{tabular}{|c|c|c|c|c|c|c|c|c|}
\hline Strongly agree/agree & $\begin{array}{c}2254 \\
(45.8)\end{array}$ & $1640(33.3)$ & $1024(20.8)$ & $<.001$ & Reference & & Reference & \\
\hline Disagree/strongly disagree & $608(26.7)$ & $865(38)$ & $802(35.3)$ & & $\begin{array}{l}1.407 \\
{[1.200} \\
1.650]\end{array}$ & $<.001$ & $\begin{array}{l}1.431 \\
{[1.188} \\
1.725]\end{array}$ & $<.001$ \\
\hline \multicolumn{9}{|l|}{$\begin{array}{l}\text { I worry the COVID-19 vaccines } \\
\text { will not be effective against new } \\
\text { virus variants }\end{array}$} \\
\hline Strongly agree/agree & $\begin{array}{c}2463 \\
(42.8)\end{array}$ & $1984(34.5)$ & $1310(22.8)$ & $<.001$ & Reference & & Reference & \\
\hline Disagree/strongly disagree & $399(27.8)$ & $521(36.3)$ & $516(35.9)$ & & $\begin{array}{l}1.109[.927, \\
1.327]\end{array}$ & .259 & $\begin{array}{l}1.245 \\
{[1.016} \\
1.525]\end{array}$ & .035 \\
\hline \multicolumn{9}{|l|}{ Cues to action } \\
\hline \multicolumn{9}{|c|}{$\begin{array}{l}\text { I will only receive the COVID-19 } \\
\text { vaccines after many others } \\
\text { receive it }\end{array}$} \\
\hline Strongly agree/agree & $\begin{array}{c}2235 \\
(42.7) \\
\end{array}$ & $1833(35)$ & $1169(22.3)$ & $<.001$ & Reference & & Reference & \\
\hline Disagree/strongly disagree & $627(32.1)$ & $672(34.4)$ & $657(33.6)$ & & $\begin{array}{l}1.068[.909, \\
1.254]\end{array}$ & .425 & $\begin{array}{l}1.103 \\
{[.913} \\
1.333]\end{array}$ & .309 \\
\hline \multicolumn{9}{|c|}{$\begin{array}{l}\text { I will only receive the COVID-19 } \\
\text { vaccines after politicians receive } \\
\text { it }\end{array}$} \\
\hline Strongly agree/agree & $\begin{array}{c}2142 \\
(43.6)\end{array}$ & $1725(35.1)$ & $1041(21.2)$ & $<.001$ & Reference & & Reference & \\
\hline Disagree/strongly disagree & $720(31.5)$ & $780(34.1)$ & $785(34.4)$ & & $\begin{array}{l}1.111[.957, \\
1.289]\end{array}$ & .167 & $\begin{array}{l}1.495 \\
{[1.256} \\
1.780]\end{array}$ & $<.001$ \\
\hline
\end{tabular}

4

5

6

7 